\title{
MODELAGEM ESPACIAL DO FLUXO DE SEMENTES DE JATOBÁ (Hymenaea courbaril), ATRAVÉS DE MARCADORES MOLECULARES, NA PAISAGEM FRAGMENTADA DO PONTAL DO PARANAPANEMA, SP
}

\author{
Renato Miazaki de Toledo
}

\begin{abstract}
Dissertação apresentada à Escola Superior de Agricultura "Luiz de Queiroz", Universidade de São Paulo, para obtenção do título de Mestre em Ciências, Área de Concentração: Ecologia de Agroecossistemas.
\end{abstract}

P I R A C I C A B A

Estado de São Paulo

Maio - 2005 


\title{
MODELAGEM ESPACIAL DO FLUXO DE SEMENTES DE JATOBÁ (Hymenaea courbaril), ATRAVÉS DE MARCADORES MOLECULARES, NA PAISAGEM FRAGMENTADA DO PONTAL DO PARANAPANEMA, SP
}

\author{
Renato Miazaki de Toledo \\ Ecólogo
}

Orientador: Prof.Dr. PAULO YOSHIO KAGEYAMA

Dissertação apresentada à Escola Superior de
Agricultura “Luiz de Queiroz”, Universidade de
São Paulo, para obtenção do título de Mestre em
Ciências, Área de Concentração: Ecologia de
Agroecossistemas.

\author{
P I R A C I C A B A \\ Estado de São Paulo \\ Maio - 2005
}


Dados Internacionais de Catalogação na Publicação (CIP) DIVISÃO DE BIBLIOTECA E DOCUMENTAÇÃO - ESALQ/USP

\section{Toledo, Renato Miazaki de}

Modelagem espacial do fluxo de sementes de jatobá (Hymenaea courbari), através de marcadores moleculares, na paisagem fragmentada do Pontal do Paranapanema, SP / Renato Miazaki de Toledo. - - Piracicaba, 2005.

63 p. : il.

Dissertação (mestrado) - - Escola Superior de Agricultura Luiz de Queiroz, 2005. Bibliografia.

1. Biodiversidade 2. Ecologia de paisagem 3. Jatobá 4. Marcador molecular 5. Sementes I. Título

CDD 634.973323

"Permitida a cópia total ou parcial deste documento, desde que citada fonte - O autor" 


\section{AGRADECIMENTOS}

Primeiramente agradeço ao apoio financeiro cedido pelo WWF Brasil, que tornou possível a coleta dos dados aqui apresentados.

Também agradeço:

Ao professor Paulo Kageyama; pelo apoio, pelo incentivo, pela cobrança e pelo fascinante desafio que originou este trabalho.

Ao professor Harold Fowler; mais uma vez... pela paciência, pelo companheirismo, pela dedicação e pelo bom humor.

À professora Maria Victória Ramos Ballester; por todo o apoio concedido.

Aos voluntários (generosos amigos) que participaram da coleta e discussão dos dados: Luiz Coelho, Camila Michelin, Paulo Rubin e Arthur Wieczorek. Também ao Aloísio Teixeira, pelos comentários e discussões.

Aos agroecologistas da Cocamp: Aderson, Amauri e Ivan; pelas lições, pela ajuda, pela fé e pelo belo trabalho.

À Edina Shizue Tourinho; tia Shi, pela grande ajuda.

Ao João Dagoberto dos Santos e à Karina Martins; pela amizade, pela competência e pela generosidade; presentes em todas as etapas deste trabalho.

À Elza, Andréia e Gabi; pela convivência no LARGEA, pela ajuda e pela orientação nas técnicas laboratoriais.

Aos “companheiros de capela”: professor Mario Moraes, mestre Dodô, Cipó, Sybele e Nivaldo.

Ao casal Paulo e Yuly, meus pais, meus maiores companheiros. 


\section{SUMÁRIO}

Página

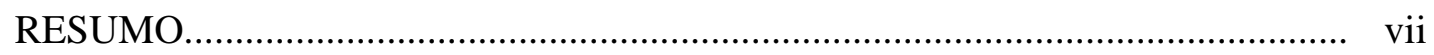

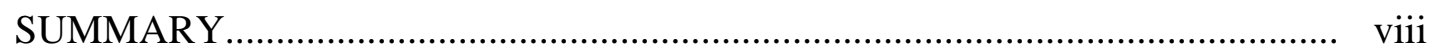

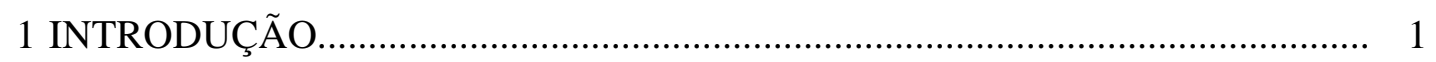

2 REVISÃO DE LITERATURA................................................................. 3

2.1 Fragmentação de habitat e suas conseqüências para biodiversidade..................... 3

2.2 Ecologia de Metapopulações............................................................................. 6

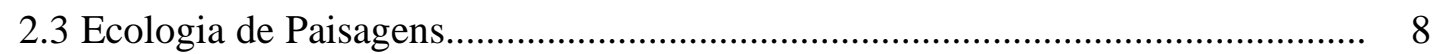

.4 Dispersão de sementes e dinâmica de recolonização em plantas....................... 11

2.5 Fluxo de sementes e marcadores moleculares..................................................... 12

2.6 Biologia reprodutiva de plantas e implicações espaciais.................................... 14

3 MATERIAL E MÉTODOS............................................................................. 17

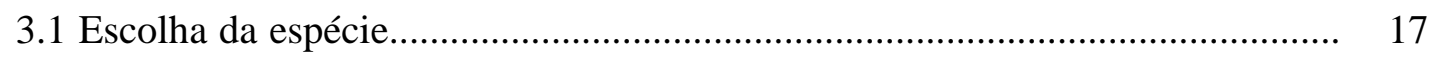

3.2 Caracterização da área de estudo.................................................................. 18

3.2.1 O Pontal do Paranapanema..................................................................... 19

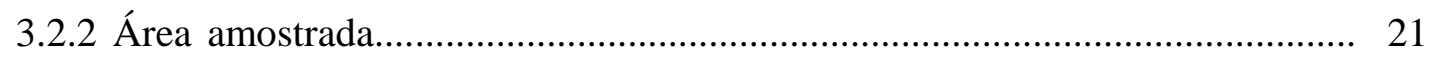

3.3 Roteiro metodológico............................................................................. 22

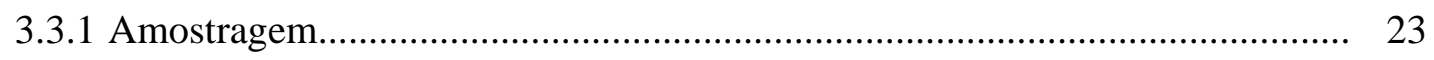

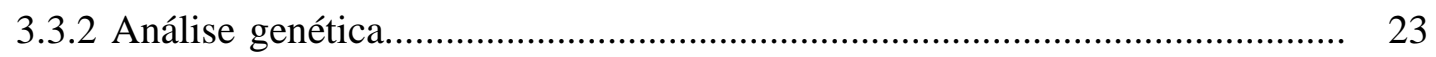

3.3.2.1 Análise laboratorial................................................................................ 23

3.3.2.2 Análise de maternidade.............................................................................. 24

3.3.2.3 Análise probabilística do fluxo de sementes................................................ 25

3.3.2.4 Análises intrapopulacionais e interpopulacionais..................................... 26

6.3.3.2 Análise da distribuição espacial de jatobá na paisagem estudada................... 27 


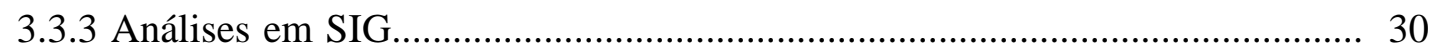

4 RESULTADOS E DISCUSSÃO................................................................... 32

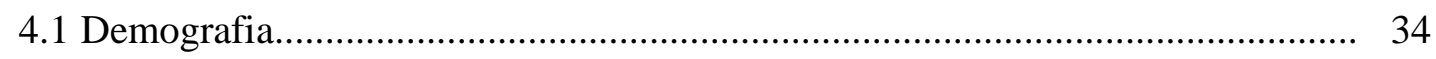

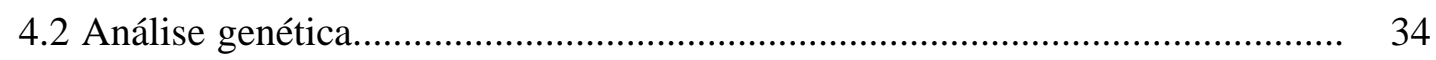

4.2.1 Análise de maternidade............................................................................. 35

4.2.2 Análise probabilística do fluxo de sementes................................................ 36

4.2.3 Análises intrapopulacionais e interpopulacionais........................................ 37

4.3 Análise da distribuição espacial da espécie na paisagem estudada.................... 40

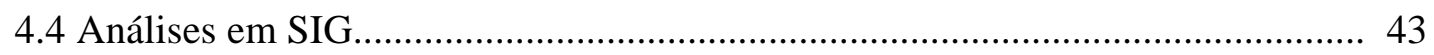

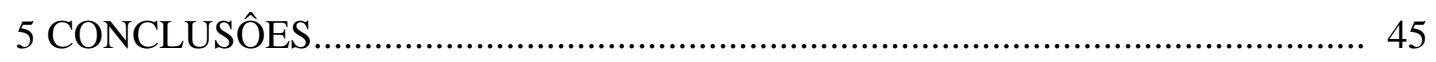

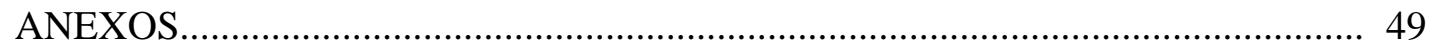

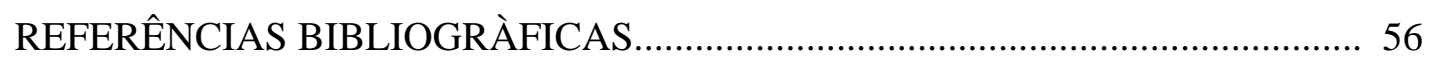




\section{MODELAGEM ESPACIAL DO FLUXO DE SEMENTES DE JATOBÁ (Hymenaea courbaril), ATRAVÉS DE MARCADORES MOLECULARES, NA PAISAGEM FRAGMENTADA DO PONTAL DO PARANAPANEMA,SP}

Autor: RENATO MIAZAKI DE TOLEDO

Orientador: Prof.Dr. PAULO YOSHIO KAGEYAMA

\section{RESUMO}

Intervenções conservacionistas baseadas em receitas generalistas e uniformes têm eficácia comprometida por serem incapazes de incorporar as particularidades de cada ecossistema e as diferentes características regionais da atividade humana. Este trabalho teve como objetivo desenvolver uma metodologia que incorporasse a avaliação espacial do fluxo gênico contemporâneo de plantas ao planejamento territorial de paisagens fragmentadas. Adotou-se o Jatobá (Hymenaea courbaril), espécie zoocórica, como espécie guarda-chuva. Localizada no Pontal do Paranapanema, a área amostral utilizada possui $49 \mathrm{~km}^{2}$, que abrigam sete sub-populações de Jatobá e $1,32 \mathrm{~km}^{2}$ de remanescentes florestais divididos em 4 fragmentos. Executamos o censo de árvores adultas e amostragem regular de indivíduos juvenis. Amostrou-se 359 indivíduos, dos quais 75 foram considerados como adultos, todos foram georreferenciados por GPS e genotipados por SSR. Analisando-se três locos de DNA genômico e um de c-DNA, foram realizados 21.225 testes de maternidade, nos quais 62 plantas jovens tiveram suas mães identificadas. A distribuição das distâncias de dispersão de sementes verificada indica que o isolamento para recolonização entre sub-populações ocorre em distâncias superiores a 1600m. Foram localizados 13 fragmentos que permaneceriam em condição 
de isolamento, mesmo após a recuperação de todas as APPs. Recomenda-se a inclusão do aumento de conectividade destas manchas, bem como do reflorestamento de todas as APPs, na lista de prioridades do planejamento da conservação da biodiversidade desta região. 


\section{SPATIAL MODELING OF THE SEED FLOW FOR Hymenaea courbaril WITH SSR, IN A FRAGMENTED LANDSCAPE AT PONTAL DO PARANAPANEMA, BRAZIL}

Author: RENATO MIAZAKI DE TOLEDO

Adviser: Prof.Dr. PAULO YOSHIO KAGEYAMA

\section{SUMMARY}

Conservationist interventions, based on general and uniform protocols, lose effectiveness by being incapable to incorporate the particularities of each ecosystem and the different regional patterns of the human activity. This research meant to develop a method that incorporates the spatial evaluation of the contemporary gene flow of plants to the territorial planning of fragmented landscape. We adopted Hymenaea courbaril as an umbrella species. Located in the Pontal of the Paranapanema (São Paulo State, Brazil), the study area has $49 \mathrm{~km} 2$, that shelters seven subpopulations of Hymenaea courbaril with $1,32 \mathrm{~km}^{2}$ are covered by forest that is separated in four patches. We censused adult trees and also regular seedlings and juveniles were regularly sampled. A total of 359 individuals were identified and georreferencered by GPS and genotyped by SSR. Analyzing 3 loci of genomic DNA and one of c-DNA, we applied a maternity test. 62 young plants had them mothers identified. The distribution of distances of seed dispersal indicates that the isolation for recolonization between subpopulations occurs in distances greater than $1600 \mathrm{~m}$, indicating that the connectivity in the studied landscape is very low for Hymenaea courbaril. 13 habitat patches were located in isolation condition, 
even after the recuperation of all the law-protected riparian-corridor areas. These results emphasized the increase of connectivity of these spots, as well as the restoration in the protected riparian areas, as some of the top priorities in the planning of the biological conservation of this region. 


\section{INTRODUÇÃO}

O problema enfocado por este trabalho é a grande perda de biodiversidade motivada por fragmentação de habitat, que sucede à retirada da cobertura natural do solo, nas manchas remanescentes da cobertura original. Em ecossistemas tropicais, fragmentos geralmente são remanescentes de florestas que foram poupados pelo desmatamento ou são produtos da regeneração em áreas que já foram exploradas e se recuperaram ao longo do tempo.

Nos últimos anos uma nova perspectiva foi trazida para o manejo de paisagens pela teoria de metapopulações: a possibilidade de conservação em redes de manchas descontínuas. Nesta abordagem, as taxas de extinção local estão sob influência da área e qualidade do habitat, e as taxas de recolonização sob influência da conectividade da paisagem.

Ainda que na última década grandes avanços tenham sido obtidos, tanto na Ecologia de Metapopulações como na Ecologia de Paisagens, o manejo de paisagens ainda é executado, quase sempre, sem a avaliação de parâmetros biológicos, tendo desta forma sua eficácia comprometida.

Frente a esse quadro, o presente trabalho visa contribuir para o manejo de paisagens fragmentadas, através do desenvolvimento de metodologias de planejamento e de avaliação de intervenções conservacionistas, que incorporem parâmetros espaciais estabelecidos por dados de fluxo gênico contemporâneo. Adotamos a análise espacial do fluxo de sementes de Hymenaea courbaril L., o jatobá, como um indicador de 
isolamento para fragmentos florestais inseridos em uma matriz de campos de pastagens, na região do Pontal do Paranapanema, extremo oeste do Estado de São Paulo.

As análises apresentadas são centradas no fluxo contemporâneo de sementes, não incluindo dados específicos ao fluxo de pólen. Desta forma focamos a pesquisa na avaliação da possibilidade de migração e colonização.

As perguntas aqui colocadas são as seguintes: a partir de qual distanciamento entre fragmentos a troca de sementes de jatobá, bem como a possibilidade de recolonização, se torna improvável na área de estudo? O que esta distância limiar representa para a atual configuração de fragmentos do Pontal do Paranapanema?

Existe a possibilidade de que as respostas destas questões permitam identificar fragmentos de maior importância para a conectividade, e novas ligações que seriam especialmente desejáveis, segundo a espécie. Estas inferências são plausíveis apenas nas situações em que são identificadas potenciais redes funcionais de dispersão.

Outra possibilidade é que as respostas destas perguntas indiquem predominância de situações de isolamento para a espécie na paisagem estudada, de forma que o distanciamento dos fragmentos torna inadequada a abordagem de redes para a análise da dispersão da espécie paisagem estudada. Nestes caso, as respostas das perguntas apresentadas podem ser utilizadas para a seleção de regiões em que a restauração florestal seria especialmente desejável por favorecer o estabelecimento de redes em cenários futuros.

Nas duas possibilidades acima apresentadas, nas quais a conectividade funcional em rede de populações deve ser, respectivamente, ampliada ou restaurada, as análises desenvolvidas geram resultados baseados em uma única espécie guarda-chuva. As informações apresentadas por este trabalho podem futuramente integrar um plano de manejo da paisagem do Pontal do Paranapanema baseado no estudo de diferentes espécies, sendo desta forma, abrigado por um “guarda-chuva multi-espécies”. 


\section{REVISÃO DE LITERATURA}

\subsection{Fragmentação de habitat e suas conseqüências para biodiversidade}

Muitos autores, tais como Jordan et al (2003), entendem que atualmente a maior forma de pressão à biodiversidade é a fragmentação de habitat. Wilcove et al (1998) levantaram as principais causas da depressão demográfica em 1880 espécies ameaçadas nos EUA, e verificaram que perda e fragmentação de habitat estão entre as principais causas para quase 90\% das espécies. Nesse levantamento fragmentação de habitat é a principal forma de pressão para todos os grupos taxonômicos. Apenas a poluição para peixes e moluscos, e a pressão de espécies invasoras para plantas e aves seriam ameaças comparáveis.

Ferraz et al (2003), em pesquisa realizada na floresta amazônica, estimaram que mesmo fragmentos de 10 mil ha perdem muitas espécies de aves quando isolados. Esta perda ocorre em velocidade bem reduzida ( $\mathrm{t}>100$ anos), permitindo que sejam adotadas medidas de manejo, porém fragmentos isolados com área inferior a 100 ha perdem a metade de suas espécies de aves em menos de 15 anos.

Geralmente a fragmentação é instalada a partir da ampliação da rede viária. As estradas têm um propósito agregador para a sociedade, porém têm um efeito desagregador sobre o meio ambiente, fatiando a paisagem em fragmentos (Forman, 2002). 
Segundo Corry \& Nassauer (2002), a fragmentação de habitat é inerente ao modelo contemporâneo de ocupação de terras. Fora das Unidades de conservação as manchas de habitat remanescentes continuam a ser diminuídas e eliminadas. Esta realidade aponta para a necessidade de que pesquisadores se dediquem mais ao estudo de pequenos fragmentos. A tentativa de reconectar estes fragmentos é uma prática recente no manejo da biodiversidade e na Ecologia de restauração. Os humanos estariam apenas começando a preservar e a conectar as peças do que uma vez foi bem maior e contínuo.

Nesta realidade atual, na qual passamos a tentar conectar manchas de habitat, uma das formas de ocupação de terra que mais se expande é a agricultura de precisão. Ao especular sobre as implicações desta forma de agricultura sobre a estrutura de paisagens, Corry \& Nassauer (2002) levantam aspectos positivos e negativos para a conservação da biodiversidade: perda de heterogeneidade da paisagem por eliminação competitiva de grande parte das pequenas propriedades, diminuição de permeabilidade da matriz e ocupação de novas áreas, seriam pontos extremamente negativos. Por outro lado: diminuição da contaminação de remanescentes por economia de insumos e abandono de manchas de solo pouco produtivas seriam pontos positivos se acompanhados de medidas eficazes de manejo de paisagens.

A tendência geral seria o aumento do número de fragmentos em áreas não protegidas condicionada pela redução da área média de fragmentos. O saldo da interação dos efeitos do aumento de precisão em campos de cultivo pode chegar a ser positivo para biodiversidade em paisagens muito perturbadas, se estivermos preparados para planejar a conservação em pequenos fragmentos, que seriam os remanescentes diminuídos, e as pequenas manchas não mais cultivadas.

Transposta para a realidade brasileira, a tendência apresentada por Corry \& Nassauer (2002) indica que a reserva legal, instituída pelo Código Florestal Brasileiro (Brasil, 1965), tende a ser representada por manchas pequenas mesmo em grandes propriedades, pois o planejamento agrícola aumenta o seu detalhamento espacial. Em 
áreas como o Pontal do Paranapanema, fora da Amazônia legal e do domínio do Cerrado, a reserva legal corresponde a 20\% da área da propriedade.

A diminuição de área média nos fragmentos desacompanhada de eficazes medidas de manejo de paisagens deve ser vista como uma grande ameaça à biodiversidade, sobretudo do ponto de vista genético.

Ouborg (1993) explica que a fragmentação age fundamentalmente reduzindo e isolando as áreas propícias à sobrevivência das populações, dando assim origem à extinções determinísticas e estocásticas. O risco destas extinções aumenta à medida que o tamanho da população é reduzido.

Em populações pequenas, o grau de parentesco entre os indivíduos pode atingir níveis restritivos em poucas gerações, comprometendo o sucesso reprodutivo e levando à extinção local da espécie. Hamrick \& Lovelles (1998) explicam que a perda de vigor decorrente da endogamia é conhecida como depressão endogâmica. A endogamia acarreta diminuição dos níveis de variação genética, resultando numa baixa taxa de recrutamento e potencial risco de extinção.

De acordo com Young et al. (1996), a fragmentação leva à redução do tamanho populacional, criando gargalos genéticos, já que os indivíduos remanescentes portam apenas uma pequena amostra do “pool” gênico original.

O tamanho das populações remanescentes é limitado principalmente pela área do fragmento. O efeito da área é especialmente importante quando a cobertura vegetal original é composta por florestas tropicais, como reforçam Kageyama \& Gandara (1999). A altíssima riqueza de espécies das florestas tropicais implica no predomínio de espécies pouco abundantes, que ocorrem em baixas densidades. A maior parte das espécies arbóreas é composta por espécies raras, altamente sensíveis ao efeito de área por serem distribuídas em pequenas populações nos fragmentos remanescentes. 
A tendência de diminuição na área média de fragmentos e a alta sensibilidade ao efeito de área em florestas tropicais indicam a condição de fragilidade a que se submete a biodiversidade inserida em paisagens fragmentadas como o Pontal do Paranapanema. Nestas paisagens, a avaliação e a restauração da conectividade são medidas de suma importância.

Tanto a avaliação como a restauração de conectividade implicam em mensuração de conectividade. Esta mensuração pode ser direcionada à conectividade estrutural ou à conectividade funcional. A conectividade estrutural é representada pela estrutura geométrica e topológica do mosaico paisagístico, sendo específica à paisagem estudada. Já a conectividade funcional é representada pela movimentação de organismos e gametas pelo mosaico paisagístico, sendo específica ao organismo estudado na paisagem estudada. Este estudo é direcionado ao estudo da conectividade funcional oferecida pela paisagem do Pontal do Paranapanema à espécie Hymenaea courbaril.

\subsection{Ecologia de Metapopulações}

Segundo Cain et al (2000), imagens aéreas da superfície de nosso planeta mostram claramente que este é um lugar de manchas. Esta natureza mosaicada de nossas paisagens mostra que populações de muitas espécies de plantas estão espacialmente isoladas. Nestas condições, o "rabo” da curva de dispersão de sementes, ou o lançamento de propágulos à longa distância, representa a única maneira pela qual populações de plantas podem trocar indivíduos ou colonizar manchas vazias de habitat. Esta dinâmica de colonização e recolonização também ocorre em mosaicos antrópicos, podendo caracterizar uma dinâmica de metapopulações.

O conceito de metapopulações fornece o paradigma teórico dominante no estudo da dinâmica de espécies em paisagens fragmentadas (Hanski, 1998). Neste modelo, uma metapopulação é formada por um conjunto de sub-populações, isoladas no espaço em diferentes fragmentos de habitat, mas, no entanto, unidas por fluxo de indivíduos, sementes e pólen (Opdam, 1991). O modelo clássico de metapopulações, derivado 
deste conceito, é mais apropriado para organismos inseridos em paisagens altamente fragmentadas, e, nesta situação, seria de grande utilidade para conservacionistas (Hanski, 2002).

O modelo clássico da dinâmica de metapopulações é evidenciado em uma espécie nas situações em que esta se distribui em sub-populações com relevante, porém não completo, isolamento e estas sub-populações são passíveis de extinção local e recolonização. Outra condição é a inexistência de sincronia na dinâmica populacional das sub-populações.

Alguns autores, tais como Mennechez (2004), têm discutido que a aplicabilidade da teoria de metapopulações terá maior sucesso quando os modelos forem menos generalistas e mais realistas, o que significaria inserir mais informações biológicas e informações sobre a dinâmica da paisagem.Verheyen et al (2004) afirmam que a incorporação da dinâmica da distribuição de habitat no paradigma de metapopulações permitirá a sua aplicação em uma ampla variedade de paisagens reais.

Hanski \& Ovaskainen (2003) fizeram uma revisão do desenvolvimento recente da teoria de metapopulações. Os trabalhos têm se centrado no desenvolvimento de modelos de ocupação de manchas, derivados de modelos estocásticos ou de aproximações determinísticas. Estes trabalhos são baseados em dados de presença e ausência em muitas dezenas de fragmentos, ou em dados de marcação e recaptura em algumas dezenas de fragmentos. Têm como objetivo estimar o tempo de persistência da metapopulação e, conseqüentemente, avaliar o grau de ameaça que sofre a espécie, bem como estimar a importância de cada fragmento na prorrogação da extinção da metapopulação. Os trabalhos apresentados pelos autores diferem bastante do presente trabalho, tanto na natureza dos dados base como nos objetivos.

O presente trabalho se vale dos avanços advindos da incorporação da teoria de metapopulações ao manejo de paisagens fragmentadas, porém não aproveita seu desenvolvimento matemático por duas razões: os dados adquiridos em campo e em 
laboratório neste trabalho são muito mais ricos, porém muito mais escassos, do que os utilizados no desenvolvimento dos modelos matemáticos, uma vez que são utilizados dados da distribuição de genótipos em sete populações e não de presença e ausência em dezenas de manchas de habitat. Outro motivo é a diferença de objetivos. A espécie arbórea Hymenaea courbaril foi utilizada por este trabalho apenas como indicadora de isolamento funcional, abrindo-se mão de gerar prognósticos sobre a espécie na paisagem estudada.

\subsection{Ecologia de Paisagens}

Segundo Turner at al (2002), a ciência Ecologia da paisagem lida explicitamente com as causas e conseqüências da heterogeneidade espacial, oferecendo conceitos e ferramentas que são diretamente relevantes para o manejo de recursos naturais em paisagens heterogêneas. Neste contexto, o isolamento de populações é o efeito mais prejudicial da fragmentação, sendo que ampliar a conectividade de paisagens é a resposta de manejo a este grande problema. Quantificar e manipular a conectividade são grandes desafios que têm sido explorados pela Ecologia de paisagens.

Uma paisagem fragmentada, em função de sua configuração espacial, pode manter diversas populações de forma sustentável. Porém, a partir de um certo grau de fragmentação, ou para uma determinada configuração espacial dos fragmentos, os efeitos da fragmentação tornam-se muito intensos e a restauração é então necessária para manter a diversidade biológica. Para uma determinada espécie, considera-se que este patamar é atingido quando a distância média entre os fragmentos torna-se maior do que a distância que a espécie é capaz de atravessar fora do seu habitat. De uma forma mais geral, considerando a comunidade como um todo, o limiar máximo de fragmentação pode ser definido quando a conectividade não compensa mais os efeitos da fragmentação (Metzger \& Décamps, 1997).

Desta maneira, a distância limiar entre fragmentos é um dado extremamente valioso para o planejamento territorial envolvido na conservação e restauração de 
paisagens fragmentadas. Na impossibilidade de cálculo da distância limiar para todas as espécies, uma alternativa seria a eleição de espécies guarda-chuva como sugere Lambeck (1997).

A idéia é que a manutenção de espécies guarda-chuva, ou aquelas mais sensíveis à fragmentação, garantiria a manutenção de todas as outras espécies menos exigentes. Estas espécies guarda-chuva podem ser agrupadas em função da característica que as torna mais exigentes ou mais ameaçadas, e a configuração da paisagem é definida em função delas (Metzger, 2004).

Do ponto de vista socioeconômico, florestas tropicais estão localizadas em regiões tidas como "em desenvolvimento", e a exploração sustentável destas paisagens é uma idéia que tem sido requisitada como uma resposta econômica aos problemas sociais e ambientais destas regiões. Ao se dedicar ao incremento de sustentabilidade ecológica em paisagens predominantemente produtivas, a Ecologia também se desenvolve ao confrontar-se com suas contradições.

Miller\& Hobbs (2002) atentam para a necessidade de que Ecólogos se envolvam mais com políticas públicas, aproximando-se dos problemas reais do planejamento ambiental. Criticam ainda os rumos dos trabalhos em Biologia da Conservação, ao constatar que se por um lado a grande maioria de hotspots se localiza em regiões com altas taxas de aumento populacional, por outro lado poucos trabalhos científicos têm sido desenvolvidos em áreas sob processo de ocupação humana. De forma que a ocupação está ocorrendo praticamente sem respaldo ou acompanhamento científico, o que seria no mínimo um desperdício para a ciência.

Turner et al (2002) denunciam um completo descompasso entre as necessidades cotidianas de manejadores e os avanços nas pesquisas em Ecologia da paisagem. Este descompasso seria originado pela diferença de metas e de compromissos entre manejadores e pesquisadores, chegando ao ponto em que estes profissionais não costumam compartilhar nem mesmo a escala de trabalho. Desta maneira os avanços 
científicos não são repassados à paisagem. Seria necessário que os pesquisadores atuassem mais em manejo, mesmo que a própria estrutura acadêmica desestimule atividades de manejo, premiando apenas o debate teórico quantificado por publicações científicas.

Bunn at al (2000) demonstram a utilização dos grafos na mensuração de conectividade específica em paisagens fragmentadas, sugerindo que este seria um avanço efetivo nas práticas conservacionistas quando a conectividade de paisagens está em questão.Os autores sugerem ainda que a simplicidade e flexibilidade de abordagens sobre a conectividade de paisagens baseadas na teoria dos grafos têm muito a oferecer aos gestores de desenvolvimento regional, ampliando o escopo e a efetividade do manejo de recursos naturais.

Urban \& Keitt (2001) explicam que o grafo representa a paisagem através dos nós e redes, que se conectam em diferentes níveis através de links, onde os nós representam populações e os links representam a união funcional de pares de populações por meio de dispersão.

As ciências exatas utilizam os grafos para avaliação e planejamento de redes complexas há bastante tempo. Já a sua incorporação à Ecologia de paisagens é bastante recente, oferecendo uma maneira simples e pragmática de se avaliar e planejar metapopulações. Nesta abordagem, considera-se a metapopulação como um sistema de rede, ou uma rede de manchas. A compreensão dos limiares espaciais de determinada espécie em uma determinada paisagem permite inferir sobre o comprimento máximo que teria um link, ou uma conexão. Desta maneira é possível relacionar todos os links existentes e estimar os limites de cada metapopulação desta espécie nesta paisagem.

Jordán el al (2003) discutem a relevância de algumas propriedades de grafos na quantificação de conectividade e propõem uma metodologia de avaliação da importância relativa de diferentes manchas e corredores na manutenção da conectividade de paisagens. Os autores explicam os princípios em que se baseia a 
metodologia proposta: as propriedades fundamentais de grafos de paisagens ou qualquer outro tipo de rede estão relacionadas à quantidade e relação entre nós e de links, com a importância de cada nó podendo ser avaliada pela quantidade de links em que participa, e também pelo efeito que sua deleção causaria na rede.

\subsection{Dispersão de sementes e a dinâmica de recolonização em plantas}

A dispersão de sementes tem intrigado naturalistas há bastante tempo. Darwin (1859) chegou a fazer testes de germinação com sementes trazidas de longe por pássaros em uma das ilhas visitadas pelo Beagle. Henry Thoreau, além de filósofo democrata e abolicionista, autor de Desobediência Civil em 1854, base teórica das ações de Mahatma Ghandi e Martin Luther King também foi um dos mais importantes naturalistas, como destacam Wilson (1994) e Formam (1995). Autor de "Walden, a vida nos bosques” (1854) e “Sucessão de árvores florestais” de 1860, Thoreau dedicou seus últimos estudos à dispersão de sementes. Estes autores sabiam que o aprofundamento no entendimento deste mecanismo é a chave para melhor compreender diversos processos ecológicos, e também sabiam, que a dispersão de sementes deve ser vista como uma grande oportunidade.

Cain et al (2000) também defendem que as dificuldades que envolvem os estudos de dispersão de sementes à longa distância são desafios que devem ser vistos como uma grande oportunidade, pois compreender os mecanismos de metapopulações de plantas é um passo fundamental para avançar no entendimento da dinâmica espaço-temporal da heterogeneidade de paisagens. Os autores ainda ressaltam que apesar de a relevância desta linha de pesquisa ser um dado relativamente antigo, poucos avanços foram obtidos até o final da última década, quando os avanços da genética molecular e a possibilidade de identificação de paternidade se difundiram nas pesquisas de dispersão a longa distância, superando as limitações de análises históricas da genética de populações. Os autores advertem que a maior dificuldade encontrada nesta abordagem é a necessidade de exaustivas coletas de campo. 
Gwenaele et al (2004) defendem que modelar a dispersão é um passo fundamental no desenvolvimento de análises de viabilidade de metapopulações. Sob o enfoque da ecologia de metapopulações, a distinção entre os efeitos dos fluxo gênicos via pólen e via sementes é especialmente importante, uma vez que os polinizadores são incapazes de promover a recolonização.

As colocações de Cain et al (2000) são reforçadas por Godoy\&Jordano (2001), que apontam que a combinação de cuidadosos desenhos experimentais em Ecologia e análises laboratoriais de marcadores moleculares pavimentam a promissora estrada para futuros estudos de mutualismo planta-frugívoro.

O presente estudo toma a distribuição espacial do jatobá como testemunha da movimentação dos animais dispersores, aproveita a oportunidade apontada pelos autores citados anteriormente, como indicador de conectividade funcional, e de alcance da possibilidade de recolonização para esta espécie na paisagem estudada.

É importante citar que a mesma relação existente entre dispersão de sementes e recolonização de espécies nativas é valida entre dispersão de sementes e colonização por espécies invasoras. O estudo da dispersão de sementes de uma planta invasora pode revelar como as estratégias de contenção desta espécie exótica podem ser aprimoradas.Wilson (1994) destaca que competição com espécies invasoras representava (em 1994) uma das principais formas de ameaça à conservação de biodiversidade, e que as estratégias de contenção, então utilizadas, eram extremamente caras e pouco eficazes.

\subsection{Fluxo de sementes e marcadores moleculares}

O crescente interesse pela dinâmica de metapopulações e pela dispersão de sementes em escala de paisagens promove novas abordagens ao estudo de fluxo gênico contemporâneo. Estas abordagens têm sido adotadas em função do desenvolvimento de novos marcadores moleculares e nos métodos estatísticos, assim como a percepção de que o fluxo gênico contemporâneo não pode ser calculado de forma confiável por 
métodos convencionais de estrutura genética. Estimativas da dinâmica espacial e temporal do fluxo de pólen e sementes, que considerem as características da paisagem remanescente, podem auxiliar biólogos evolucionistas e conservacionistas a predizer respostas demográficas e genéticas às subdivisões populacionais naturais e antropogênicas (Sork et al. 1999).

Neste sentido, pesquisas envolvendo a dispersão de sementes têm se apropriado dos avanços obtidos em marcadores moleculares, demonstrando uma tendência à preferência por análise de paternidade através de marcadores de microssatélites, tais como em: Kameyama et al (2001), Godoy \& Jordano (2001) e Gaiotto et al. (2003).

Gaiotto et al (2003) explicam as vantagens da análise de paternidade através de marcadores de microssatélites: "Um método direto de se avaliar o fluxo gênico em populações naturais é através de testes de paternidade entre os indivíduos da população com baterias de microssatélites, também conhecidos como seqüências simples repetidas (SSR). Altamente informativos e discriminantes, estes marcadores têm sido utilizados em estudos de populações naturais por serem: multialélicos, altamente polimórficos, codominantes, abundantes, uniformemente distribuídos no genoma e facilmente obtidos em ensaios de PCR”.

Wang \& Smith (2002) compararam as diferentes técnicas de coleta de dados de dispersão de sementes de longa distância, e concluíram que a análise de paternidade por marcadores moleculares é o método mais poderoso por ser direto, porém é também o mais caro, por ser o mais trabalhoso. Os autores incentivam os trabalhos na área defendendo que, apesar de a dispersão em longas distâncias ser um evento extremamente raro, a probabilidade de recrutamento desta planta cresce bastante, bem como a importância do estabelecimento desta planta na composição da vegetação. Ressaltam, ainda, que esta linha de pesquisa é de grande importância para que se possa modelar a disseminação de espécies invasoras. 
Cain et al (2000) previam que um avanço ainda maior seria obtido pela incorporação de dados sobre o genoma de organelas citoplasmáticas, como o DNA mitocondrial e o cloroplastídico. Para a maioria das plantas esta informação genética não é transmitida via polén, não participando do cruzamento e sendo de herança materna. Desta forma é possível separar o fluxo gênico de polinização do fluxo gênico de dispersão. Kitamoto et al (2005) investigaram o fluxo gênico de populações de prímulas através de marcadores de microssatélites (SSR), diferenciaram o fluxo via semente e o fluxo via pólen através de DNA cloroplastídico, e detectaram que, nas populações estudadas, o fluxo via pólen é mais importante nas planícies e o fluxo via sementes é mais eficiente ao longo dos rios.

\subsection{Biologia reprodutiva de plantas e implicações espaciais}

O fluxo gênico de vegetais superiores se concretiza em três eventos efêmeros cíclicos: polinização, dispersão de sementes e recrutamento. A compreensão destes eventos é necessária para que se possa prever a degeneração de populações por endogamia. Cada espécie possui uma resposta espacial própria para cada uma destas etapas.

A etapa de polinização é determinada pela distância que o polinizador pode percorrer carregando o pólen, delimitando a área em que cada árvore poderá disponibilizar genes durante sua floração. A mesma relação é estabelecida entre a árvore e o dispersor quando os frutos amadurecem, o que delimita a sombra de sementes (seed-shadow). A heterogeneidade da paisagem também interfere na delimitação destas áreas, principalmente em paisagens fragmentadas, devido à limitação da ação de polinizadores e dispersores. Kageyama \& Gandara (1994) ressaltam que a distância de vôo do polinizador tem importantes conseqüências genéticas para as populações, pois existem grandes diferenças entre os hábitos na visita das flores, o que tem relação direta com a distância efetiva que o pólen alcançaria na floresta. 
Santos (2002) avaliou o fluxo gênico via pólen de jatobás (Hymenanea courbaril) através de testes de paternidade baseados na análise de 5 locos de microssatélites nucleares. Este trabalho indica que os polinizadores de jatobás promovem a troca de gametas entre árvores com distâncias de até $7 \mathrm{~km}$. Embora seu trabalho não tenha incluido medidas diretas de dispersão de sementes, registrou a observação de anta (Tapirus terrestris), veado (Mazama sp), queixadas (Tayassu pecari) e macaco-prego (Cebus apella) alimentando-se de frutos de jatobá. Além da frugivoria registrada, o autor observou também a dispersão de sementes sendo efetivada por macaco-prego e anta, verificou-se a germinação de sementes descartadas pelo macaco-prego e de sementes defecadas por anta.

O recrutamento pode ser entendido como o período de desenvolvimento da planta que vai desde o estágio final de plântula até se tornar um indivíduo adulto (capaz de se reproduzir) (Crawley, 1997). O recrutamento ocorre dentro da sombra de sementes, sob efeito de condições edáficas e de duas variáveis ecológicas: predação e competição. Harper (1977) descreve esta fase como sendo a peneira ambiental, a presença ou ausência de plântulas não depende apenas da disponibilidade de sementes, mas também da oferta de locais seguros que proporcionem as condições necessárias para desenvolvimento de cada semente. O recrutamento seleciona onde e quais genótipos estarão disponíveis nas próximas florações.

De acordo com o modelo Janzen-Connell (Janzen, 1970), a predação de sementes e plântulas possui um certo grau de predictibilidade, ocorrendo com maior intensidade próxima aos indivíduos adultos, onde a densidade de sementes e plântulas é maior num primeiro momento. Isto faz com que o recrutamento ocorra preferencialmente longe de indivíduos adultos, em locais de baixa densidade de sementes. $\mathrm{O}$ autor conclui que este fato contribui para que diferentes espécies se estabeleçam na mesma redondeza, o que em parte explicaria a alta diversidade de espécies da floresta tropical.

Competição intra e interespecífica, por sua vez, recrutam através de mecanismos bióticos e abióticos dependentes, que fazem com que o microhabitat seja propício ou 
hostil ao desenvolvimento de determinada planta. Dentro da dinâmica florestal a relativa estabilidade regional se apresenta através de instabilidade local, onde se evidencia a sucessão de espécies.

Compreender como a espécie interage com a heterogeneidade da paisagem, assim como quais são as condições que lhe são favoráveis e garantem maior probabilidade de sobrevivência e sucesso reprodutivo, é um passo primordial em estudos de Ecologia da Paisagem, permitindo o mapeamento de habitat. Para saber o que a espécie considera como habitat é importante saber quais condições são estressantes em qual escala esta espécie interage com o ambiente. Uma condição que deve ser testada é o efeito de borda.

Cada espécie teria uma relação diferente com a borda do fragmento, tanto em termos de distâncias como no tipo de resposta; os tipos de respostas possíveis seriam: as aversas, as exploradoras e as indiferentes. Isto faz com que o tamanho do fragmento seja relativo entre as espécies. A área efetiva de uso é especifica e produto da resposta da espécie à borda, tamanho e forma do fragmento (Sisk \& Haddad, 2002).

Entender a resposta de uma espécie ao efeito de borda possibilita compreender melhor como esta espécie “enxerga” a paisagem, e quais são os fragmentos provedores de habitat para a espécie. Espécies muito sensíveis ao efeito de borda podem não encontrar habitat em fragmentos muito pequenos e/ou pouco compactos, desta forma a dinâmica de recolonização não pode se valer destes fragmentos como fonte ou como receptor de migrantes e colonos. 


\section{MATERIAL E MÉTODOS}

\section{1.- Escolha da espécie}

A espécie Hymenaea courbaril L. pertence à família Leguminosae, subfamília Caesalpinioideae. Esta espécie ocorre desde o Estado do Paraná até o Estado da Bahia. A espécie é alógama, possui síndrome de polinização predominantente quiropterófila e síndrome de dispersão predominante mamaliocórica. O Jatobá corre risco de extinção e consta na lista das espécies prioritárias pelo Instituto Florestal de São Paulo, para conservação genética “ex situ” (Siqueira, 1992).

A madeira desta árvore possui alto valor comercial, a polpa do fruto é utilizada como alimento e popularmente são atribuídas à resina propriedades medicinais, sendo utilizada como tônico, para doenças pulmonares e diversas infecções.

Trata-se de uma espécie arbórea de árvore perenifólia a semicaducifólia, podendo atingir até 25 metros de altura e $120 \mathrm{~cm}$ de DAP, possui tronco reto e cilíndrico. Apresenta copa grande e arredondada com densa folhagem. Possui casca externa na cor cinzenta-clara, quase lisa a áspera, com pequenos sulcos superficiais; e espessura com até $10 \mathrm{~mm}$. A casaca interna é rosada e exuda resina cor de vinho. Suas folhas são compostas, coriáceas, brilhantes com dois folíolos, de bases desiguais e com até $12 \mathrm{~cm}$ de comprimento por $5 \mathrm{~cm}$ de largura. As flores são hermafroditas, de cores brancas e creme, reunidas em corimbo, tendo em média 14 flores terminais. O fruto é do tipo vagem lenhosa, indeiscente, meio cilíndrica, dura, pouco comprida, de coloração marrom brilhante, internamente revestida por poupa carnosa, farinácea, com odor característico e comestível. Mede de $12 \mathrm{~cm}$ a $17 \mathrm{~cm}$ de comprimento e a 5 de largura, e 
contém de 2 a 8 sementes. As sementes são cor de vinho, ovaladas com tamanho e forma variáveis, em média com 2 cm de comprimento (Santos, 2002).

Para a escolha da espécie estudada, o primeiro critério adotado foi relativo à disponibilidade das informações ecológicas, que seriam utilizadas no estudo. A espécie também deveria ter ampla área de ocorrência, que incluísse o Pontal do Paranapanema, e ser de interesse para o manejo, além de se enquadrar como espécie guarda-chuva.

O jatobá também foi escolhido por já ter o fluxo de pólen estudado por Santos (2002), de forma que já havia um protocolo específico para análise de microssatélites desenvolvido. A escolha também revela a opção por contribuir para o detalhamento da descrição da biologia reprodutiva, e do fluxo gênico contemporâneo, para uma espécie relativamente bem estudada, e não por iniciar estudos para uma espécie.

Podemos considerar o Jatobá como espécie guarda-chuva, uma vez que ocorre em baixas densidades e a morfologia de seus frutos torna o sistema de dispersão de sementes especialmente delicado, sendo necessária a participação de grandes mamíferos frugívoros para que se atinja longas distâncias. A produção de frutos ainda exige a atuação de morcegos polinizadores, interação estudada por Santos (2002) e Dunphy et al (2004).

\subsection{Caracterização da área de estudo}

\subsubsection{O Pontal do Paranapanema}

A região do Pontal do Paranapanema corresponde ao extremo oeste do Estado de São Paulo. Segundo Ditt (2000), os limites da região são formados a oeste pelo Rio Paraná, ao sul pelo Rio Paranapanema, a leste pelo Rio Laranja Doce e Ribeirão dos Guachos, e ao norte pelo Rio do Peixe. Esta área corresponde à extinta Grande Reserva do Pontal do Paranapanema. 
O Pontal do Paranapanema insere-se na província geomorfológica conhecida como Planalto Ocidental de São Paulo. Colinas amplas são as formas de relevo locais, com baixas declividades (menos de 15\%) e interflúvios com mais de $4 \mathrm{Km}^{2}$ (Ponçano et al., 1981).

O solo é originário de rochas do grupo Bauru, sendo Latossolo o tipo prédominante na região. Além da elevada concentração de areias, destacam-se como principais características a baixa fertilidade natural, boa permeabilidade e drenagem excessiva (Cadernos Itesp2, 1998).

Veloso et al. (1991) classificam a vegetação do Pontal do Paranapanema como “Floresta Estacional Semidecidual”. Ela é condicionada pela presença de duas estações climáticas: tropical, com intensas chuvas de verão seguidas por estiagens acentuadas; e subtropical, sem período seco, mas com seca fisiológica provocada pelo frio do inverno. De 20 a 50\% das árvores são caducifólias. Os mesmos autores afirmam que essa cobertura florística originou-se na flora do escudo Atlântico, refugiada no Pliopleistoceno.

O processo de ocupação agrícola do Pontal do Paranapanema é relativamente recente. Entre 1941 e 1942, o governado estadual de São Paulo decretou que toda a área oeste do Pontal do Paranapanema passaria ser uma reserva de fauna e flora. Segundo Dean (1996), nos anos 50, o então Governador do Estado Ademar de Barros distribuiu as terras da reserva entre amigos e correligionários, que iniciaram um voraz processo de ocupação do solo. Devido a essa ocupação sem critérios, o Pontal do Paranapanema sofreu drástica redução em sua cobertura florestal.

Santos (2002) complementa que recentemente ocorreu o processo de reocupação territorial por grupos de agricultores organizados, nos últimos anos, pelo Movimento dos Trabalhadores Rurais Sem Terra (MST). O autor ainda registrou que haviam 4500 famílias assentadas em glebas no pontal do Paranapanema, ocupando 38.000 ha. O autor também apresenta a projeção futura do assentamento de 50.000 famílias em 1.000.000 de ha de terras devolutas do oeste paulista. 
Atualmente, dos 247.000 ha que compunham a grande reserva do Pontal do Paranapanema, aproximadamente 200.000 ha se encontram desmatados. De toda a área apenas 32\% abrangem propriedades particulares regularizadas. A maior porção das florestas remanescentes concentra-se no Parque Estadual do Morro do Diabo, que possui uma área de 35.000 hectares. A tabela 1 apresenta a fragmentação dos demais 12.000 ha.

Tabela 1. Número de fragmentos por classe de tamanho no Pontal do Paranapanema

\begin{tabular}{cc}
\hline Área (ha) & Número de fragmentos \\
\hline $5-50$ & 273 \\
$50-100$ & 32 \\
$100-200$ & 20 \\
$200-400$ & 9 \\
$400-800$ & 6 \\
$800-1600$ & 3 \\
$1600-2000$ & 2 \\
\hline
\end{tabular}

Adaptado de: Ditt (2000)

Os dados apresentados por Santos (2002) e Ditt (2000) demonstram a urgência pelo desenvolvimento do planejamento do manejo de paisagens para a região do Pontal do Paranapanema, bem como a grande importância ecológica dos fragmentos remanescentes para a conservação da ecoregião dos “bosques atlânticos de interior”.

A fase de regularização de propriedades e implementação de assentamentos de reforma agrária pode ser vista como uma grande oportunidade para direcionar a evolução da paisagem do Pontal. Tomadas de decisão, tais como escolhas de prioridades, terão maior chance de êxito se existir a disponibilidade de trabalhos científicos, como os relativos à fragmentação, sobre a área de estudo. O presente trabalho pretende somar às análises apresentadas por Ditt (2000) e Santos (2002).

A região foi escolhida para o presente trabalho em função de três características: a presença de grande número de fragmentos florestais, o histórico de recente 
fragmentação e a urgência por planejamento territorial numa região que está em pleno processo de reocupação rural, através de assentamentos de reforma agrária.

\subsection{2. Área amostrada}

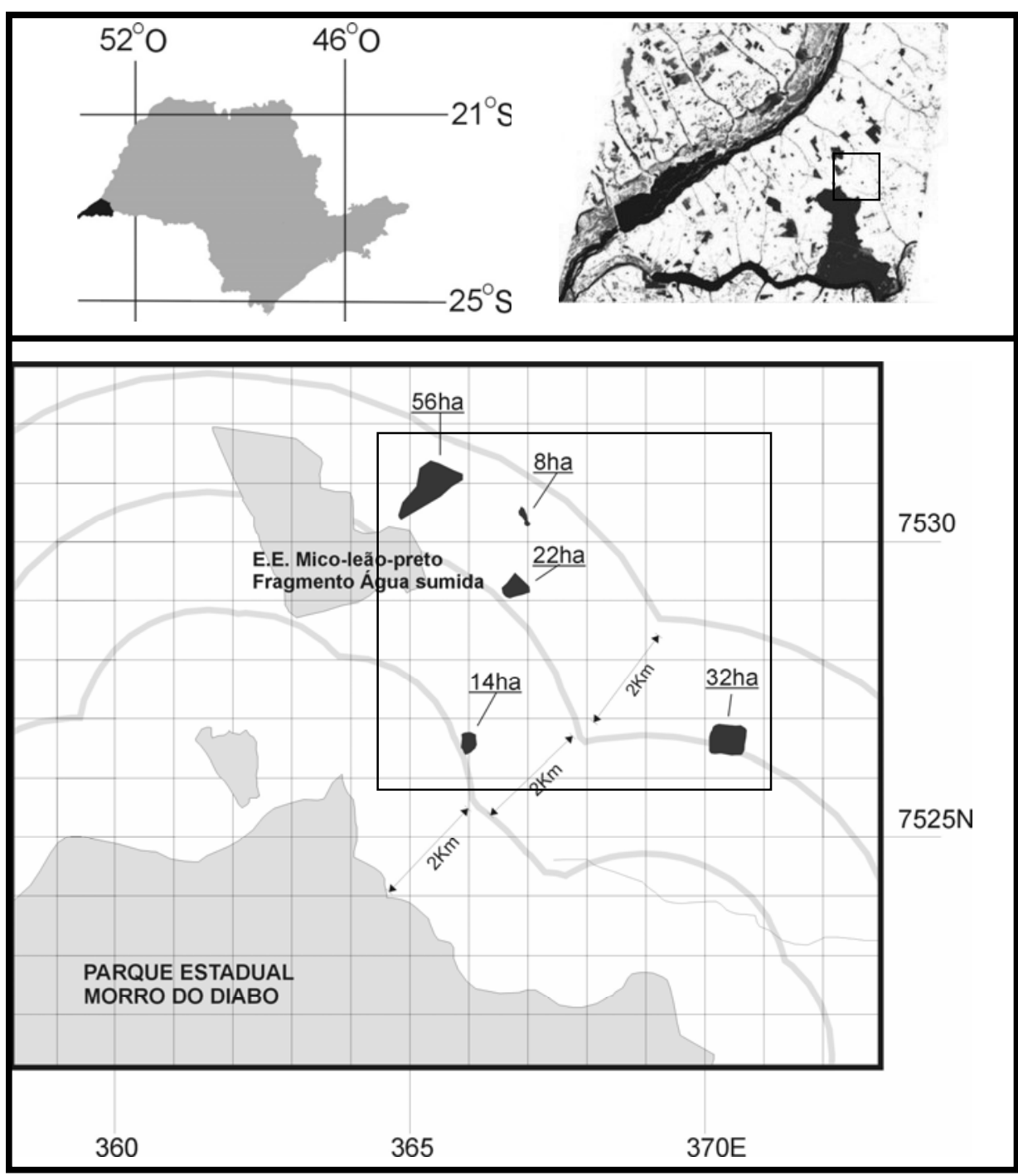

Figura 1- Contexto espacial e área dos fragmentos amostrados (UTM em Km)

Foram amostrados 4 remanescentes florestais (56ha, 22ha, 32ha e 14ha). Apenas o fragmento de 56 hectares, indicado na figura 1, faz parte da Estação Ecológica Micoleão-preto. A mancha de 8 ha corresponde a uma área em regeneração. A figura 1 ainda indica o distanciamento entre os fragmentos e o Parque Estadual Morro do Diabo. 
A Estação Ecológica Mico-leão-preto foi criada em 2002 e é formada por três fragmentos distantes entre si, sendo que apenas a unidade “Água Sumida” consta na Área de Estudo. Até 2002 este fragmento pertencia à reserva legal do assentamento “Água Sumida”, implantado pelo INCRA na década de 80.

O fragmento “Água Sumida” foi quase inteiramente consumido por grandes incêndios em 2001 e 2002. Na figura 1, a área queimada é apresentada em cinza, sob o rótulo da Estação Ecológica. Nesta unidade foi amostrado apenas o fragmento formado pelos 56 hectares poupados pelos incêndios.

Os fragmentos de 32 ha, 14 ha e 22 ha indicados na figura 1 estão inseridos em fazendas, assim como a mancha de 8ha. A mancha faz divisa com o assentamento “Água Sumida”, e não foi considerada como fragmento, por não ser remanescente da cobertura vegetal original e por não apresentar estrutura florestal, os indivíduos amostrados nesta área foram considerados como regenerantes.

\subsection{Roteiro metodológico}

Para estimar a distância limiar de dispersão de jatobá no Pontal do Paranapanema, respondendo à primeira pergunta deste trabalho, foram seguidos os seguintes passos: Amostragem georreferenciada de Hymenea courbaril, análise de maternidade baseada em marcadores de microssátelites, análise estatística das distâncias de dispersão encontradas e confronto com análises de estrutura genética das populações.

Para verificar as implicações desta distância limiar para a paisagem do Pontal do Paranapanema, respondendo à segunda pergunta deste trabalho, verificou-se primeiramente se a espécie apresentava restrições de habitat e se era sensível ao efeito de borda. Esta primeira análise, baseada na distribuição espacial dos indivíduos amostrados, permitiu o mapeamento de fragmentos segundo a espécie. Sobre este mapeamento foram executadas expansões de perímetro baseadas na distância limiar 
obtida, o que permitiu a avaliação da conectividade da paisagem, segundo a espécie Hymenaea courbaril.

A metodologia de cada um destes passos é apresentada detalhadamente a seguir.

\subsubsection{Amostragem}

Os indivíduos adultos de Jatobá foram censeados através de caminhamento sistemático nos quatro fragmentos, sendo que a varredura foi feita com trilhas paralelas, distando 30 metros entre si. O levantamento em pastos foi feito aproveitando-se a rede viária das fazendas e do assentamento Água Sumida. Os indivíduos foram georreferenciados em sistema de coordenadas planas (UTM) e datum SAD 69 através de um receptor GPS. Foram computados para cada indivíduo: CAP (circunferência à altura do peito), presença de frutos e altura. Também foi recolhido tecido foliar como amostra de material genético.

Toda as plântulas e indivíduos jovens encontrados ao longo do censo também foram amostrados. Cada indivíduo teve tecido foliar coletado e altura, CAP e coordenadas geográficas registradas.

A metodologia de localização de plantas empregada privilegiou a localização de indivíduos de maior porte, pois estes eram mais facilmente visualizados. Estimamos que todos os indivíduos adultos foram amostrados, já que a maior parte deles foi reamostrada uma ou duas vezes; e que apenas cerca de um quinto das plântulas foi localizado, uma vez que a visibilidade de sub-bosque era em média de três metros

\subsubsection{Análise genética}

\subsubsection{Análise laboratorial}

A extração do DNA genômico total das amostras foi realizada seguindo o protocolo CTAB descrito por Ferreira \& Grattapaglia (1995). Após a quantificação de DNA as amostras foram diluídas em água MiliQ a 2,5ng/ $\mu$ l. 
Os indivíduos foram genotipados com três locos microssatélites nucleares desenvolvidos para Hymenaea courbaril no CENARGEN/EMBRAPA (dados não publicados) e um loco SSR cloroplastidial desenvolvido por Weising \& Gardner (1999)

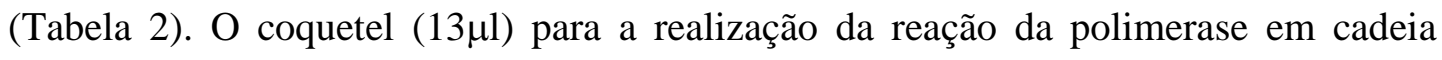
(PCR) foi composto por 15,0ng de DNA genômico, $250 \mu \mathrm{M}$ de dNTPs, $0,5 \mu \mathrm{M}$ de $\mathrm{MgCl}_{2}$, tampão para PCR 1X (10mM de Tris-HCl, 50mM de $\mathrm{KCl}, 1,5 \mathrm{mM}$ de $\mathrm{MgCl}_{2}$, $\mathrm{pH}$ 8.3), 2,5 $\mu \mathrm{g} / \mathrm{ml}$ de BSA, $0,2 \mu \mathrm{M}$ de cada iniciador e $1 \mathrm{U}$ de Taq DNA polimerase (Phoneutria). As amplificações foram realizadas em termociclador do tipo MJ Research PTC-100 utilizando o seguinte protocolo: $96^{\circ} \mathrm{C}$ por 2 minutos; 30 ciclos de $94^{\circ} \mathrm{C}$ por 1 minuto, temperatura de hibridação específica de cada par de iniciadores por 1 minuto, $72^{\circ} \mathrm{C}$ por 1 minuto e terminando com $72^{\circ} \mathrm{C}$ por 7 minutos.

Após a amplificação, os fragmentos de DNA foram separados em gel desnaturante de poliacrilamida a 5\% e observados na forma de bandas, após coloração com nitrato de prata, seguindo o protocolo de Creste et al. (2001). O tamanho dos alelos foi determinado por comparação com um marcador de peso molecular padrão (10-pb ladder - Gibco). Fragmentos amplificados de diferentes tamanhos foram considerados alelos diferentes.

Tabela 2 . Locos de microssatélites nucleares com as respectivas temperaturas de hibridação $\left(\mathrm{T}_{\mathrm{m}}\right)$, amplitudes alélicas em pares de base e amplitude alélica

\begin{tabular}{cccc}
\hline Locos de SSR & $\mathrm{T}_{\mathrm{m}}\left({ }^{\circ} \mathrm{C}\right)$ & Número de alelos & Amplitude alélica $(\mathrm{pb})$ \\
\hline HC 35 & 58 & 8 & $268-290$ \\
HC 40 & 60 & 15 & $150-192$ \\
HC 42 & 58 & 10 & $118-148$ \\
Ccp2 & 58 & 3 & $190-210$ \\
\hline
\end{tabular}

\subsubsection{Análise de maternidade}

Foi utilizado o método de exclusão com base na comparação dos genótipos dos 75 indivíduos com CAP maior que 60cm amostrados, com cada um dos 283 indivíduos 
com CAP menor que $60 \mathrm{~cm}$. Foram utilizados nos genótipos os três locos microssatélites nucleares e o loco cloroplastidial.

Adotou-se $60 \mathrm{~cm}$ de CAP como parâmetro artificial de maturidade, pois o indivíduo amostrado de menor circunferência, que apresentava frutos na copa ou no solo, sob a copa, possuía 63cm de CAP.

Foram executados 21225 testes de maternidade. Para tanto, foram organizadas 4 matrizes em planilhas de cálculo, uma para cada loco; "CAP maior que $60 \mathrm{~cm}$ ” em colunas e "CAP menor que $60 \mathrm{~cm}$ " em linhas, testando todas as possibilidades de maternidade. Foi considerada a imprecisão de dois pares de base na interpretação dos géis.

Uma quinta matriz foi gerada pela multiplicação entre as matrizes anteriores, avaliando a possibilidade de maternidade considerando todos locos que foram analisados. Com a adição de locos, representados por planilhas, o número total de valores máximos na matriz resultante vai diminuindo. Chegando-se a um único valor máximo, a mãe era possivelmente identificada; novos locos confirmavam ou descartavam esta maternidade.

Para cada indivíduo com CAP menor que $60 \mathrm{~cm}$ avaliou-se primeiramente a possibilidade de maternidade dentro do fragmento. Quando nenhuma possível mãe era encontrada, partia-se para os outros fragmentos.

\subsubsection{Análise probabilística do fluxo de sementes}

Tendo como base a identificação de maternidades e a coordenada geográfica em UTM de "mães” e "filhos”, foram calculadas as distâncias associadas às maternidades, distâncias referentes à dispersão de sementes. 
A distribuição dos valores das distâncias de dispersão, conseguidos pelo cálculo da distância entre "árvores-mãe” e filhas, foi analisada estatisticamente através de um procedimento computacionalmente intensivo.

A distribuição da distância máxima foi estimada através de bootstrap paramétrico. Inicialmente, o teste de Kolmogorov-Smirnov foi aplicado para verificar se as distâncias se distribuem segundo uma distribuição gama.

O bootstrap consistiu na geração de 2000 amostras de tamanho $\mathrm{n}=62$ de uma distribuição gama com média e variância dadas pelos valores amostrais. A análise dos valores máximos de cada replicação permitiu a elaboração do modelo probabilístico. A técnica utilizada está descrita em Efron \& Tibshrani (1993).

Assumindo que uma plântula migrante, ou colonizante, também possui baixa probabilidade de recrutamento, entendemos que o fluxo de sementes não pode ser um evento raro caso se pretenda contar com o recrutamento de migrantes e colonos. Desta maneira, a distância máxima esperada deve ter alta probabilidade de ocorrência. Foi estimado o percentil 95 da distância máxima em amostras de tamanho 62.

\subsubsection{Análises intrapopulacionais e interpopulacionais}

Para os marcadores microssatélites nucleares, as freqüências alélicas foram estimadas por: $\not_{i j}=n_{i j} / n_{\cdot j}$, em que $\ddot{p}_{i j}=$ freqüência do alelo $i$ na população $j ; n_{i j}=$ número de ocorrência do alelo $i$ na população $j$; $n_{\cdot j}=$ número total de alelos amostrados na população $j$. com uso do programa $\mathrm{F}_{\mathrm{STAT}}$ (Goudet,1995).

A diversidade genética dentro das populações foi analisada pela heterozigosidade

observada ( $\hat{H}_{o}$ ), heterozigosidade esperada pelo equilíbrio de Hardy-Weinberg $\left(\hat{H}_{e}\right)$, número médio de alelos por loco $(\hat{A})$ e índice de fixação de Wright $(\hat{f})$, estimativas estas obtidas a partir do programa GDA (Lewis \& Zaykin, 1999). 
O tamanho efetivo populacional foi obtido com base no valor de $\hat{F}_{I S}$ estimado para cada população de acordo com o seguinte estimador:

$$
N_{e}=\frac{n}{1+\hat{F}_{I S}}
$$

onde: $N_{e}$ é o tamanho efetivo populacional; $n$ é o número de indivíduos amostrados; $\hat{F}_{I S}$ é o índice de fixação alélica estimado.

A estrutura genética foi caracterizada pela análise da variância das freqüências alélicas (Weir, 1996). Os parâmetros estimados para os microssatélites nucleares foram: coeficiente médio de endogamia dentro das populações $(\hat{f})$; coeficiente de endogamia total da espécie $(\hat{F})$ e coeficiente de coancestralidade entre indivíduos das diferentes populações ou divergência genética entre populações $\left(\hat{\theta}_{P}\right)$. Estimou-se o intervalo de confiança a 99\% de probabilidade pelo método de reamostragem bootstrap, utilizandose 10.000 repetições sobre locos. Os parâmetros relacionados acima foram estimados com o auxílio do programa GDA de Lewis \& Zaykin (1999).

O fluxo gênico ( $\mathrm{Nm}$ ) foi calculado por via indireta a partir dos valores estimados de $\hat{F}_{S T}$ (diversidade genética entre populações). O fluxo gênico para microssatélites nucleares foi calculado de acordo com o modelo proposto por Wright (1951):

$$
N m=\frac{1}{4}\left(\frac{1}{\hat{F}_{S T}}-1\right)
$$

Substituiu-se $P_{S T}$ por $\nexists_{P}$ conforme sugerem Cockerham e Weir (1984), para uma estimação de fluxo gênico não viesada.

Os padrões de variação espacial foram analisados utilizando-se o coeficiente de correlação de Pearson (r) entre a matriz de distâncias genéticas de Nei (1978) entre pares de populações e a matriz de distâncias geográficas entre as populações. A significância da correlação foi testada por meio da estatística Z de Mantel (Mantel, 1967), utilizando-se 1000 permutações, com uso do programa NTSYS (Rolf, 1989). 
A estrutura genética foi visualizada por meio de dendrograma construído a partir das distâncias genéticas de Nei (1978) utilizando o critério de agrupamento UPGMA, com uso do programa GDA (Lewis \& Zaykin, 1999).

\subsubsection{Análise da distribuição espacial da espécie na paisagem estudada}

Para caracterizar a seleção de habitat da espécie estudada, primeiramente foram realizadas entrevistas com: pesquisadores, mateiros da região e também com pessoas que, décadas atrás, trabalharam na extração de madeira. A informação resultante, e posteriormente reforçada durante o trabalho de campo, foi de que a distribuição do jatobá não está relacionada com nenhuma variável física de escala local; a espécie ocorreria em todos os ecótopos terrestres do Pontal do Paranapanema, sem a restrição de barreiras edáficas.

Assumindo esta informação como verdadeira, investigou-se a relação da espécie com o efeito de borda. Primeiramente, como análise exploratória, foi executada a análise geoestatística da distribuição de plântulas, jovens e adultos no maior fragmento estudado, onde a amostragem era suficiente para a análise. Ushizima et al (2003) explicam que a krigagem é altamente informativa para plantas de distribuição espacial agregada, e que o variograma é um eficiente avaliador de agregação também para plantas.

Os indivíduos amostrados no fragmento foram divididos em três classes segundo o CAP: 42 “adultos” (CAP $>60 \mathrm{~cm}) ; 57$ “jovens” $(60 \mathrm{~cm}<\mathrm{CAP}>0)$ e 75 "plântulas” $(\mathrm{CAP}=0$, nos quais a altura é inferior à $1,3 \mathrm{~m})$; onde a classe “adultos” representa sucesso de recrutamento, o grupo “jovens” representa a faixa etária com mortalidade associada à competição e o grupo “plântulas” representa a faixa etária com mortalidade associada à predação.

A análise geoestatística empregada baseou-se em dois processos: definição do grau de autocorrelação entre os dados pontuais, e interpolação dos valores em áreas não amostradas, baseados no grau de autocorrelação encontrado. 
Como método interpolador foi adotada a krigagem indicativa, pois, o objetivo da análise era confrontar a distribuição de indivíduos adultos (estabelecidos antes e durante a fragmentação) com a distribuição de jovens e plântulas (estabelecimento pósfragmentação). Para tanto, elaborou-se isopletas probabilísticas da distribuição das proporções densidades de plântulas / densidade de adultos e densidade de jovens/ densidade de adultos.

Com o objetivo de testar e analisar as correlações espaciais entre adultos e plântulas, e entre adultos e jovens, foram elaborados semivariogramas, com auxílio do software VARIWIN. Os modelos mais adequados para os variogramas encontrados foram os modelos exponenciais para ambos os casos como recomendam Landim \& Sturaro (2002). Os parâmetros são apresentados na tabela 2. Os fenômenos apresentaram-se isotrópicos, ou seja, a variável apresentou continuidade espacial semelhante em todas as direções. Desta maneira optou-se pelo cálculo do semivariograma omnidirecional.

Tabela 3. Modelo e parâmetros para os variogramas experimentais ajustados para o modelo teórico exponencial, para Plântula / Adulto e Jovem / Adulto. Coefeito pepita, C- Soleira e A- Alcance

\begin{tabular}{ccccc}
\hline Cortes & Modelo & Co & C & A \\
\hline Plântula / Adulto & Exponencial & 0.095 & 0.24 & 360 \\
Jovem / Adulto & Exponencial & 0.17 & 0.25 & 230 \\
\hline
\end{tabular}

As hipóteses geradas após esta análise exploratória foram testadas por análise de variância (ANOVA) considerando-se as categorias de distância da borda (0-50, 50100, 100-150, 150-200 e >200) e a classe diamétrica da planta (plântula, jovem e adulta), seguindo-se metodologia apresentada por Neter et al (1996). 


\subsubsection{Análises em SIG}

A utilização de SIG (Sistemas de Informações Geográficas) para visualização e análise dos dados obtidos ocorreu em duas etapas. A primeira etapa refere-se ao mapeamento dos dados coletados, permitindo a visualização da distribuição dos indivíduos, das populações e dos eventos dispersivos amostrados. Na segunda etapa, confrontou-se o mapeamento de fragmentos do Pontal do Paranapanema, com as restrições de habitat de Hymenanea courbaril e a distância limiar estimada para o evento estudado, a dispersão de sementes de jatobá na paisagem fragmentada do Pontal do Paranapanema. Estas etapas se desenvolveram em dois bancos de dados organizados e analisados com auxílio software ArcGis9.

O primeiro banco de dados possui maior detalhamento espacial, a escala é limitada pela acurácia das leituras do receptor GPS, entre 8 e 20 metros. Foram inseridos neste banco de dados o mapeamento de jatobás, com a localização, CAP, altura e genótipo de cada indivíduo coletado. Também foi inserido o mapeamento de vetores referentes aos fluxos de sementes identificados em laboratório.

O mapa base, utilizado na segunda etapa dos trabalhos em SIG, foi elaborado por Uezu et al. (2002), a partir de imagens Landsat, tendo 30m de resolução espacial. O mapa base foi vetorizado, gerando dois arquivos de forma: drenagem e fragmentos.

A segunda etapa partiu da adaptação do mapeamento de fragmentos, que consta no mapa base, para a espécie estudada. Verificou-se a necessidade de exclusão de fragmentos ou alteração de áreas baseando-se na análise da distribuição espacial da espécie. Estas alterações são feitas no sentido de mapear manchas de habitat para a espécie, excluindo áreas em que ocorrem situações restritivas. Esta adaptação incluiu como variáveis apenas o efeito de borda e a cobertura vegetal, uma vez que já haviam sido descartadas barreiras edáficas.

A avaliação de conectividade da paisagem estudada foi elaborada a partir de um mapa temático, composto pelo mapeamento de manchas de hábitat e de um buffer de 
800m, realizado sobre cada mancha. Em seguida a os polígonos resultantes foram rasterizados e unidos por sobreposição, para então serem novamente vetorizados automaticamente. Desta maneira cada mancha de habitat sofreu uma expansão de 800m, metade do valor da distância limiar estimada. As manchas, em que é provável a troca de sementes de jatobá, entram em contato e formam subgrupos, ou sub-grafos, que podem configurar potenciais redes de trocas de indivíduos, ou potenciais metapopulações de jatobá.

Para tornar possível a análise de um cenário onde toda a APP ripária foi reflorestada, foi necessária a utilização do arquivo de forma referente à rede de drenagem. Sobre os vetores de drenagem foi realizado um buffer de 830 metros; 30 metros referentes à APP ripária e 800 metros referentes à metade da distância limiar de dispersão estimada. Foram então inseridos os polígonos de manchas de hábitat e suas respectivas expansões de $800 \mathrm{~m}$. 


\section{RESULTADOS E DISCUSSÃO}

\subsection{Demografia}

Foram localizados 358 indivíduos de jatobá, que se distribuem em 7 agrupamentos. Estes agrupamentos foram provisoriamente considerados como subpopulações, esta divisão posteriormente foi testada e confirmada por análises genéticas.

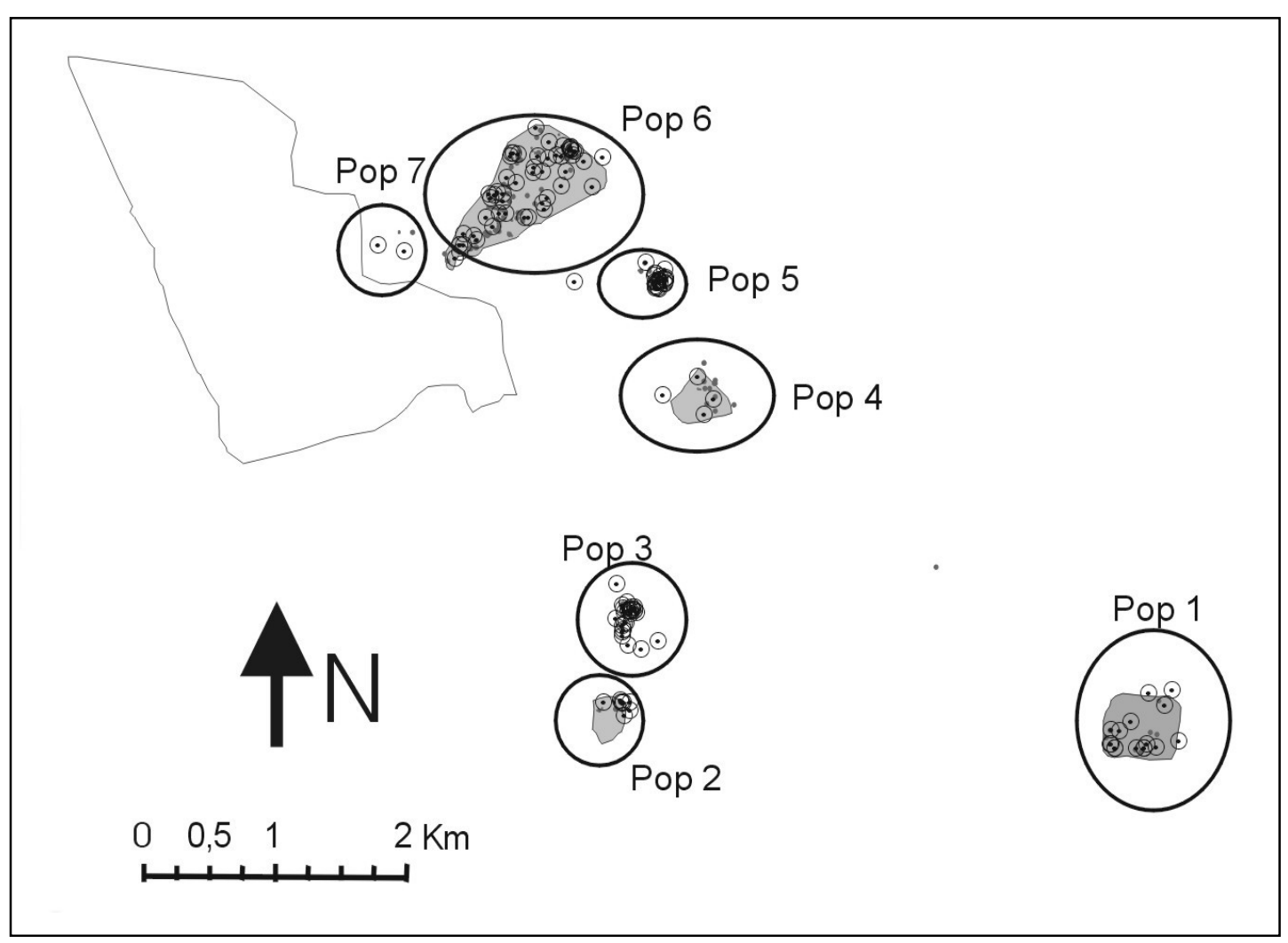

Figura 2 - Populações estudadas 
Tabela 4. Número de indivíduos amostrados por sub-população

\begin{tabular}{ccccccc}
\hline pop1 & pop2 & pop3 & pop4 & pop5 & pop6 & pop7 \\
\hline 32 & 21 & 32 & 28 & 37 & 192 & 18 \\
\hline
\end{tabular}

A distribuição de CAPs não indica sincronia entre as populações. O gráfico exibido na figura 3 indica a ausência de classes intermediárias na população 7, de indivíduos jovens na população 3 e de grandes matrizes na população 5. Também é perceptível grande variação quanto à classe mais amostrada em cada subpopulação.

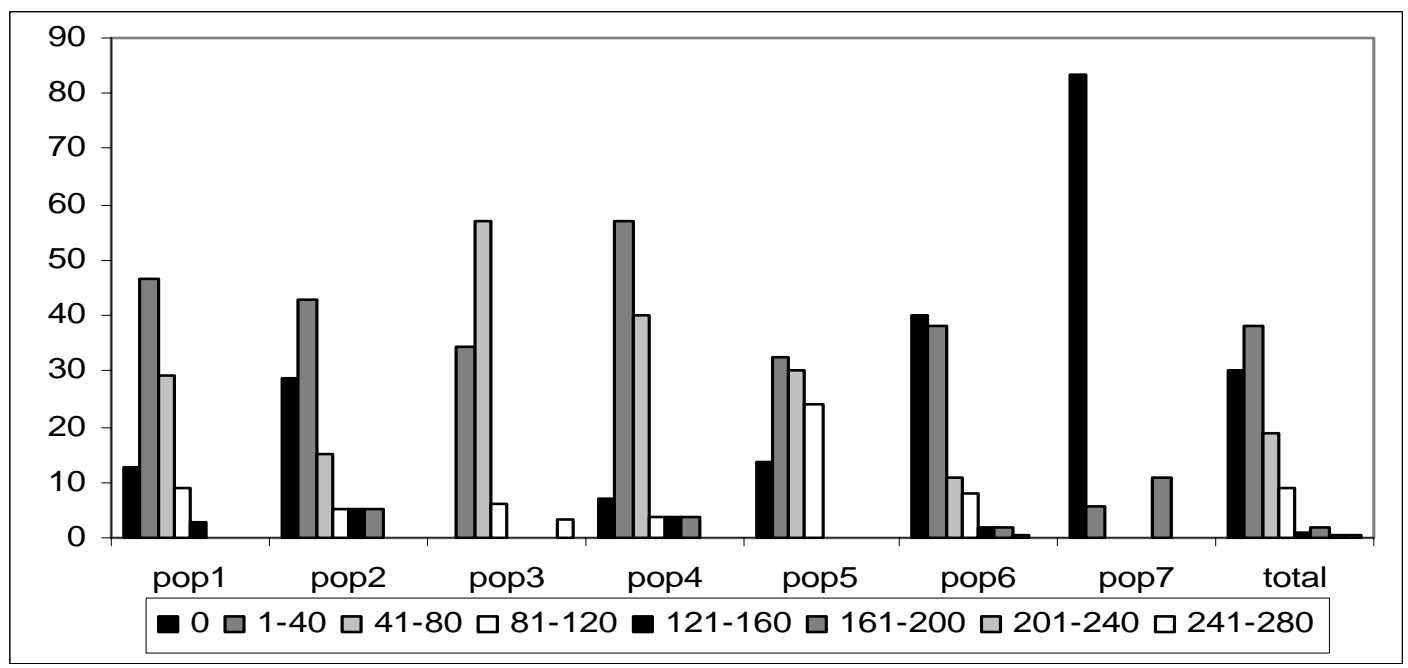

Figura 3 - Distribuição de CAP(\%) nas populações locais

O fragmento que possui o maior número de indivíduos adultos é o remanescente do fragmento Água Sumida, que abriga a população 6. Neste fragmento foram encontrados 29 indivíduos adultos. Este dado indica que à priori não existem populações isoladamente viáveis na área de estudo. A sobrevivência destas populações, em longo prazo, dependeria de fluxo gênico entre populações, sem o qual o parentesco entre indivíduos aumentaria criticamente ao longo das gerações. 
As populações 3, 5 e 7 estão localizadas entre fragmentos, em regiões de pastos em regeneração, sempre próximos a cercas. É provável que estas populações sejam testemunhas de rotas dos animais dispersores. O padrão de distribuição de CAP nestas populações é bem distinto do padrão médio, exibido em “total”, e de populações inseridas em fragmentos, populações 1,2,4 e 6. Reforçando a hipótese de que estas populações são mais novas, e que se estabeleceram após a fragmentação.

\subsection{Análise genética}

\subsubsection{Análise de maternidade}

Foram detectadas 62 maternidades, mapeando 62 eventos de dispersão. Destes eventos, 43 representam o fluxo de sementes dentro das populações e 19 representam o fluxo entre populações. 221 indivíduos não tiveram a mãe identificada. Nestes casos, a ausência de alelos menos comuns nos locos estudados não permitiram eliminações suficientes. Os mapeamentos das dispersões de sementes verificadas são apresentados em anexos A, B e C.

Outra limitação encontrada para a determinação de maternidades foi o número baixo de haplótipos identificados por Ccp-2. Foram encontrados três haplótipos sendo que um destes foi encontrado em apenas dois indivíduos adultos. Desta forma muitas vezes a exclusão de maternidade por parte do "pai”, origem do pólen, foi impossibilitada por coincidência de haplótipo.

Não foi detectado nenhum fluxo de sementes interpopulacional para a população 1, o que pode levantar a hipótese de isolamento para esta população. Esta população encontra se a $2 \mathrm{~km}$ do Parque Estadual Morro do Diabo, que abrigaria os indivíduos de jatobá mais próximos, seguida por população 3, que dista 3,8km da população 1 .

A população 6 apresentou participação em 16 dos 19 eventos de fluxo de sementes amostrados. Esta alta participação pode ser explicada pelo fato desta população ser a maior dentre as amostradas, sendo responsável por mais da metade dos 
indivíduos coletados. O fragmento em que esta população se insere é maior que os demais, e que possivelmente oferece condições mais favoráveis às antas.

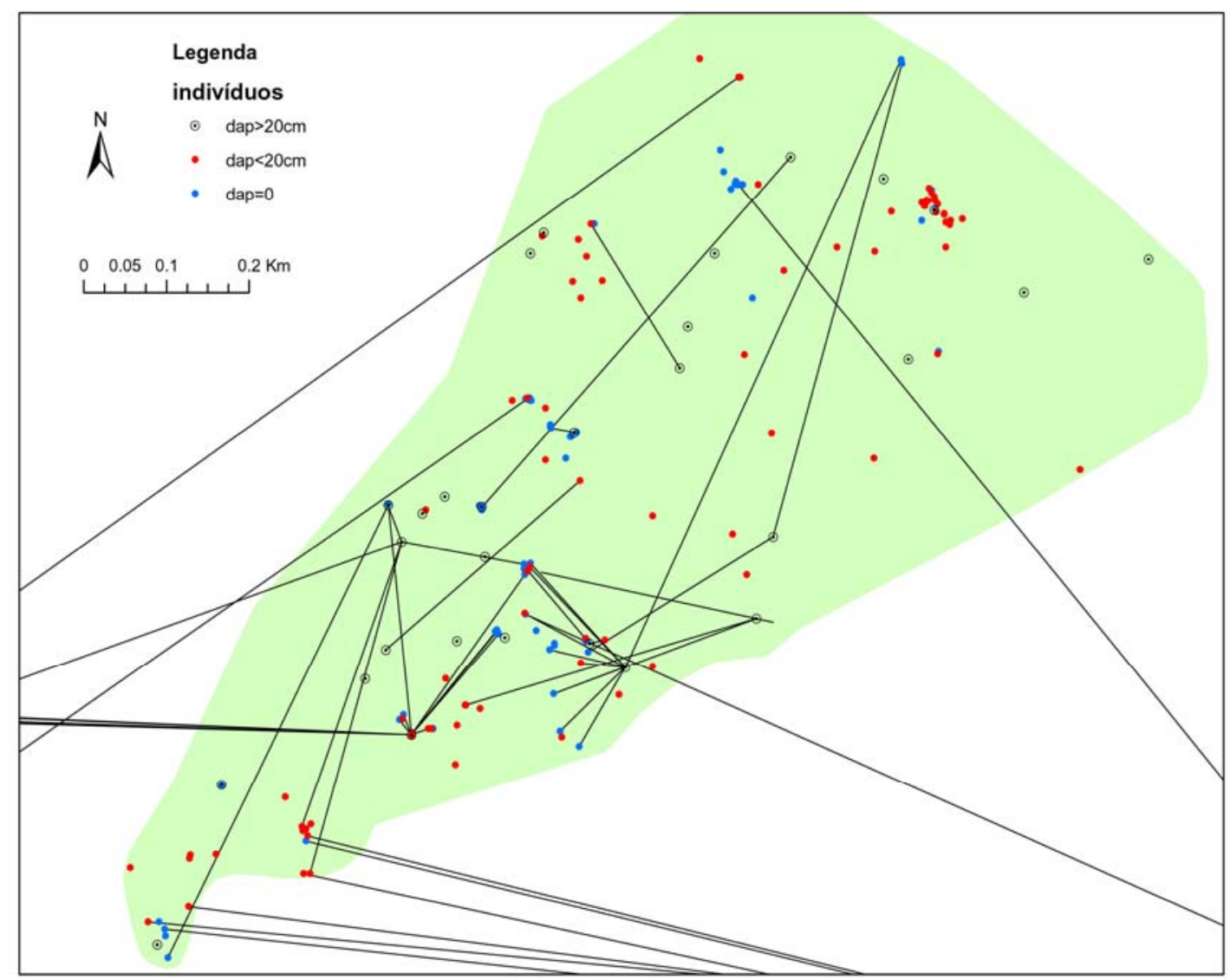

Figura 4 - Fluxos de semente de Jatobá mapeados na floresta remanescente do fragmento Água Sumida (população 6). Os indivíduos mapeados estão divididos em classes de tamanho. As linhas representam os fluxos de sementes identificados em laboratório. O polígono verde, que representa a floresta remanescente, tem como limite sudoeste uma área de campo aberto, que pertence à Estação Ecológica Mico Leão Preto, os outros limites da floresta representam os limites oficias da Unidade de Conservação. O mapeamento de todos os indivíduos e fluxos identificados são apresentados em anexo. 
A população 5 apresenta o segundo maior número de fluxos interpopulacionais detectados, foram detectados 10 eventos entre populações e nenhum fluxo dentro da população. O alto número de fluxos interpopulacionais pode ser explicado pelo contexto espacial privilegiado desta população, encontrando-se entre duas populações, a apenas 700m de cada uma. O número baixo de fluxos dentro da população pode ser explicado pelo baixo número de plântulas e indivíduos jovens identificados para esta população. Foram identificados nesta população 15 indivíduos adultos, 17 jovens e apenas 5 plântulas.

\subsubsection{Análise probabilística do fluxo de sementes}

O teste de Kolmogorov-Smirnov foi aplicado segundo uma gama com a média e a variância amostral, iguais a 491 e 275335, respectivamente. O teste não mostrou evidências para a rejeição da hipótese de distribuição gama (p > 0.10).

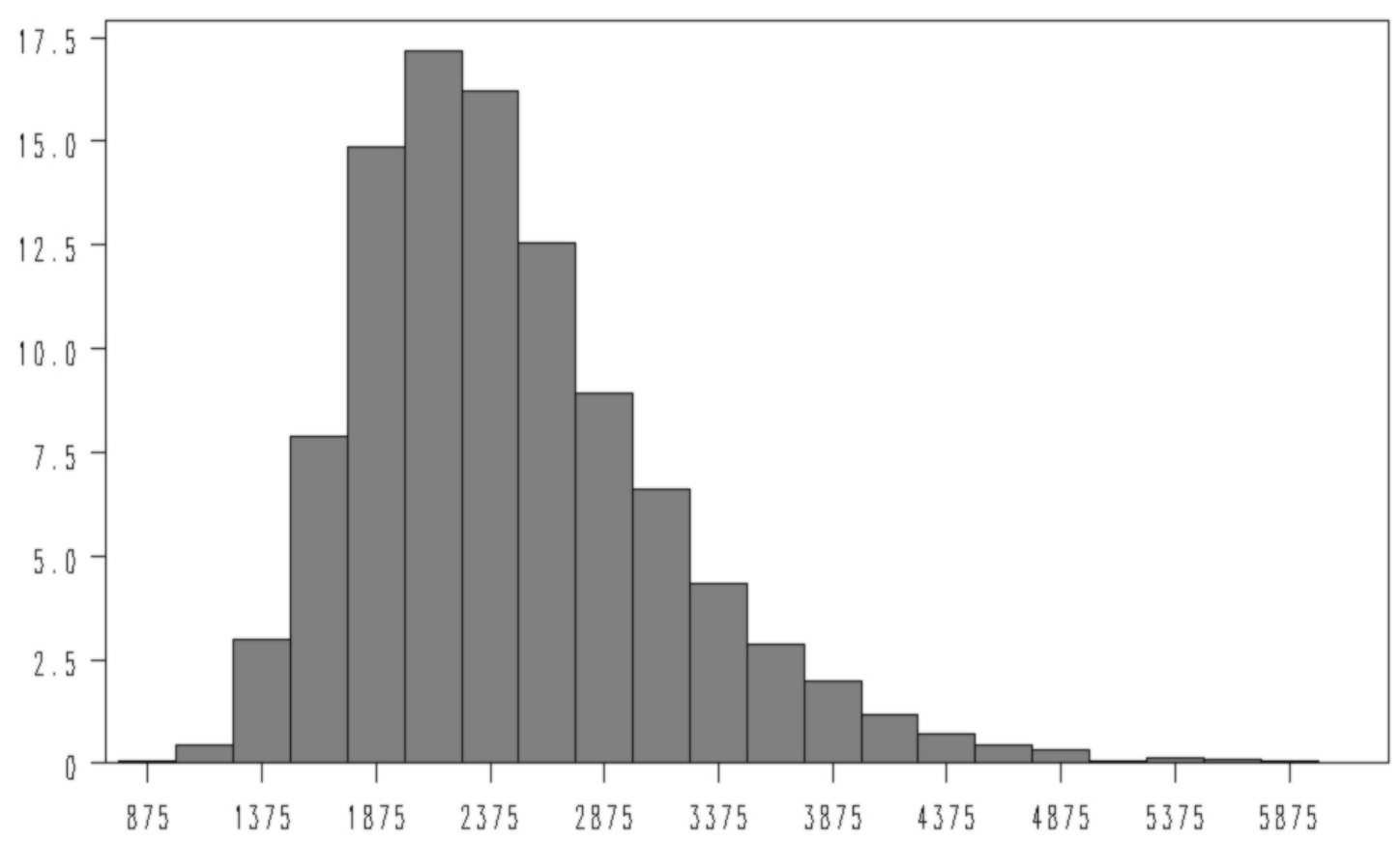

Figura 5- Histograma da distribuição de bootstrap (distância x freqüência\%) 
Como resultado da análise de bootstrap, temos que em uma série de 62 amostras de distâncias de dispersão de sementes, existe a probabilidade de 0,95 de se obter valores máximos iguais ou superiores a 1600 metros. Adotamos esta distância como sendo o limite máximo para eventos ordinários de dispersão de sementes de jatobá na área de estudo.

A distribuição de valores empíricos, apresentada na figura 6, mostra maior continuidade até $300 \mathrm{~m}$ que representam o fluxo de sementes dentro dos fragmentos. A maior descontinuidade para valores referentes ao fluxo entre fragmentos reflete não apenas a menor amostragem destes eventos como também as restrições impostas pela paisagem, uma vez que alguns intervalos de distâncias só levam de populações para o pasto aberto.

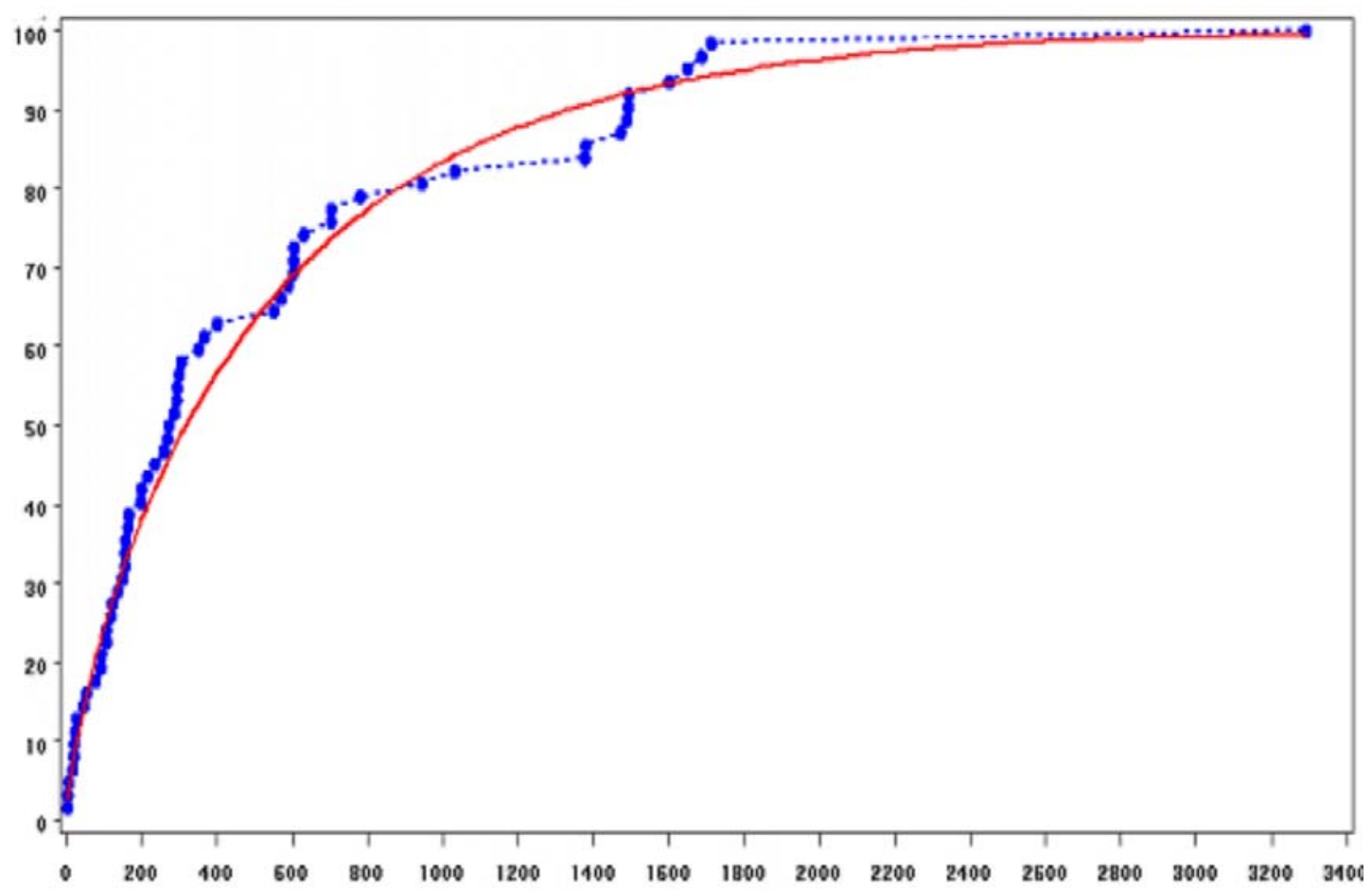

Figura 6 - Distribuição de valores máximos acumulados em metros, empírica em azul e gama em vermelho 
Na maior parte das populações, esta probabilidade (de 0,95 para 62 eventos) é bastante inferior, considerando-se que a densidade amostrada de jatobás adultos nos fragmentos é baixa (0,32/ha) e que a maior parte dos fragmentos tem área inferior a 50 ha. Seria excesso de otimismo acreditar que os poucos indivíduos adultos, abrigados nestes pequenos fragmentos, são capazes de gerar 62 descendentes adultos.

\subsubsection{Análises intrapopulacionais e interpopulacionais}

A população 1 registrou heterozigozidade esperada $\left(\mathrm{H}_{\mathrm{e}}=0,74\right)$ bastante superior a heterozigosidade observada $\left(\mathrm{H}_{0}=0,51\right)$, resultando em alto índice de fixação de Wright $(f=0,31)$, o que não ocorreu com as populações 5 e 7 . Este dado pode ser decorrente do aumento de cruzamentos entre indivíduos aparentados motivado por fragmentação. O que reforça a distância limiar de dispersão estimada (1600m), uma vez que a população 1 dista apenas 2km do Parque Estadual Morro do Diabo, e o elevado índice de fixação observado indica condição restritiva de isolamento.

Os altos valores do índice de fixação para as populações 1, 2, 3, 4 e 6, podem indicar que a fragmentação já implica em efeitos negativos para a heterozigozidade das populações estudadas, mesmo se tratando de um processo recente de fragmentação, considerando-se o longo ciclo de vida da espécie estudada. Os dados apresentados na tabela 5 não são conclusivos pois outros fatores, que não a fragmentação, também podem contribuir para a diminuição de heterozogozidade.

Os baixos valores de $f$ para populações 5 e 7 reforçam a hipótese de que estas são populações constituídas predominantemente por colonos, de forma que os efeitos do isolamento e do tamanho da população sobre a heterozigozidade só se aplicariam às próximas gerações.

Excetuando-se as populações 5 e 7, observou-se que a heterozigosidade observada foi inferior à diversidade gênica, resultando nos valores elevados de índice de fixação (f), indicados na Tabela 5. 
Tabela 5. Genética descritiva das sete populações de Hymenaea courbaril amostradas.

Parâmetros obtidos sem divisão de classes de CAP: número de indivíduos genotipados (n), número médio de alelos por loco (A), população efetiva $\left(\mathrm{N}_{\mathrm{e}}\right)$, diversidade alélica $\left(\mathrm{H}_{\mathrm{e}}\right)$, heterozigosidade observada $\left(\mathrm{H}_{\mathrm{o}}\right)$ e índice de fixação de Wright $(f)$

\begin{tabular}{ccccccc}
\hline População & $n$ & $\mathrm{~N}_{\mathbf{e}}$ & $\hat{A}$ & $\hat{H}_{e}$ & $\hat{H}_{o}$ & $\hat{f}\left(\mathrm{IC}_{99 \%}\right)^{*}$ \\
\hline 1 & 31,67 & 24,14 & 7,66 & 0,74 & 0,51 & $0,31(0,16$ a 0,47$)$ \\
2 & 20,00 & 15,89 & 5,00 & 0,58 & 0,43 & $0,25(0,12$ a 0,41$)$ \\
3 & 31,33 & 26,75 & 6,00 & 0,66 & 0,55 & $0,17(0,13$ a 0,23$)$ \\
4 & 26,66 & 22,44 & 7,00 & 0,59 & 0,49 & $0,18(0,13$ a 0,21$)$ \\
5 & 37,00 & 37,45 & 6,33 & 0,58 & 0,59 & $-0,01(-0,19$ a 0,11$)$ \\
6 & 180,66 & 154,81 & 9,00 & 0,66 & 0,55 & $0,16(0,14$ a 0,19$)$ \\
7 & 17,66 & 20,90 & 3,66 & 0,51 & 0,58 & $-0,15(-0,20$ a $-0,11)$ \\
média & 49,28 & 42,96 & 6,38 & 0,62 & 0,53 & 0,14 \\
\hline
\end{tabular}

*(IC) intervalo de confiança a 99\% de probabilidade, usando 1000 reamostragens bootstrap sobre locos.

O baixo valor da média de heterozigozidade esperada é, em parte, explicado pela baixa média geral do número de alelos por locos. Valores baixos de $\hat{A}$ (número médio de alelos por locos), como na população 7 , se justificam pela baixa abundância de indivíduos na população.

Tabela 6. Estatísticas dos parâmetros de estruturação genética obtidas para sete populações. Intervalo de confiança a 99\% obtido através de 10.000 bootstraps sobre locos

\begin{tabular}{ccc}
\hline Parâmetro & Valor estimado & Intervalo de Confiança \\
\hline$f$ & 0,1588 & 0,1341 a 0,1955 \\
$F$ & 0,1826 & 0,1472 a 0,2211 \\
$\theta_{p}$ & 0,0283 & 0,0151 a 0,0420 \\
\hline
\end{tabular}


Os parâmetros de estruturação genética obtidos para as populações de jatobá indicam que a endogamia total foi elevada $(F=0,1826)$ como conseqüência, principalmente, do valor significativo da endogamia devido ao sistema de reprodução $(f$ $=0,1588$ ). O valor de $\theta$, embora tenha sido baixo, foi significativo e indica que $2 \%$ da diversidade genética existente se deve à divergência entre as populações estudadas (Tabela 6). A estimativa baixa, porém significativa, de $\theta$ pode ser explicada por efeito de escala de amostragem, onde a distância intrapopulacional máxima foi de 4100m.

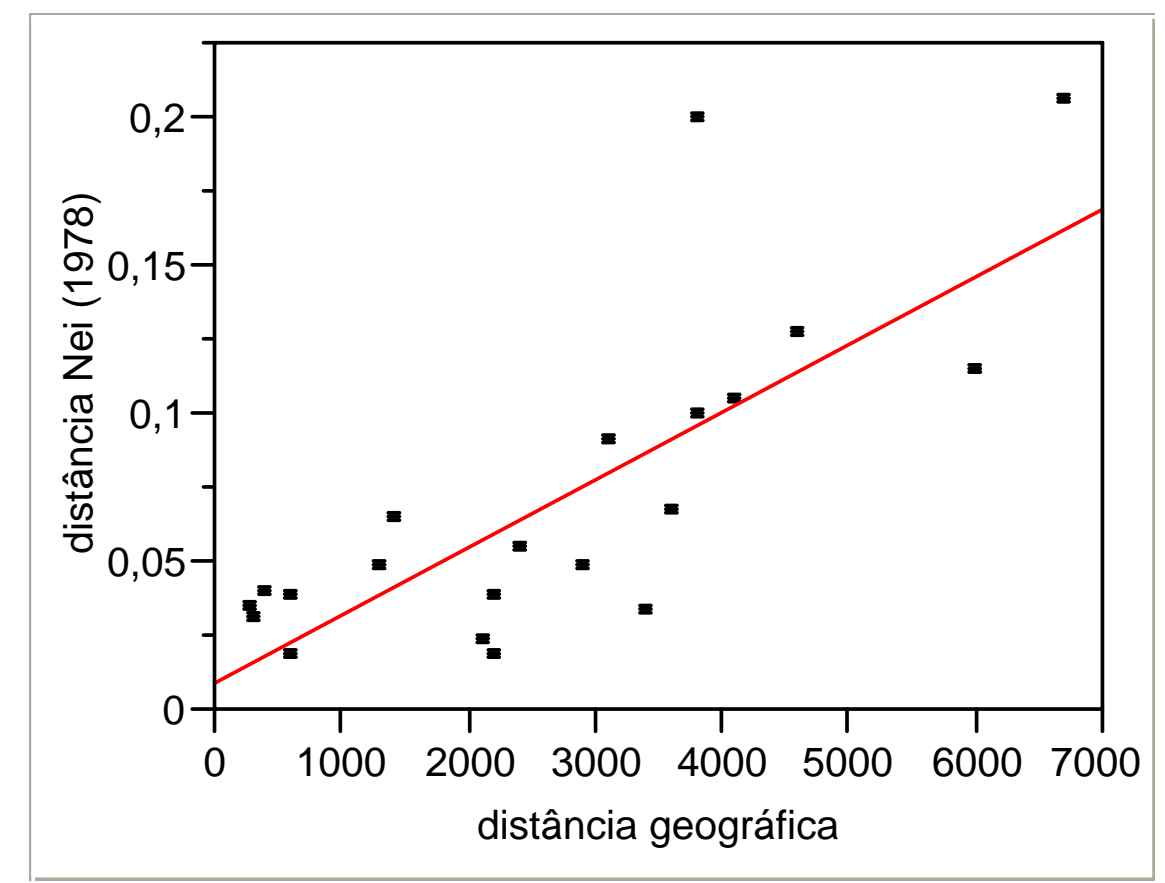

Figura 7 - Correlação entre distâncias genéticas de Nei (1978) e distâncias geográficas.

O teste de correlação de matrizes de Mantel indica $\mathrm{p}=0,009$ e r=0,7493.

O teste de correlação espacial entre distância genética de Nei (1978) e distâncias geográficas demonstrou significativa correlação positiva. Esta correlação seria esperada mesmo em paisagens contínuas, a fragmentação apenas ampliaria o efeito do distanciamento genético. Na figura 7 podem ser verificados dois pontos discrepantes, que apresentam distanciamento genético bem superior ao esperado. Estes pontos são 
referentes aos distanciamentos entre a população 1 e as populações 2 e 7, estes pontos são indicativos de aumento de distanciamento genético por fragmentação para população 1, mesmo padrão é apresentado no dendrograma de agrupamento UPGMA (figura 8).

O dendrograma apresentado em figura 8 ainda indica potencial fluxo gênico entre as populações 2,3, e 4 e entre as populações 5,6 e 7.

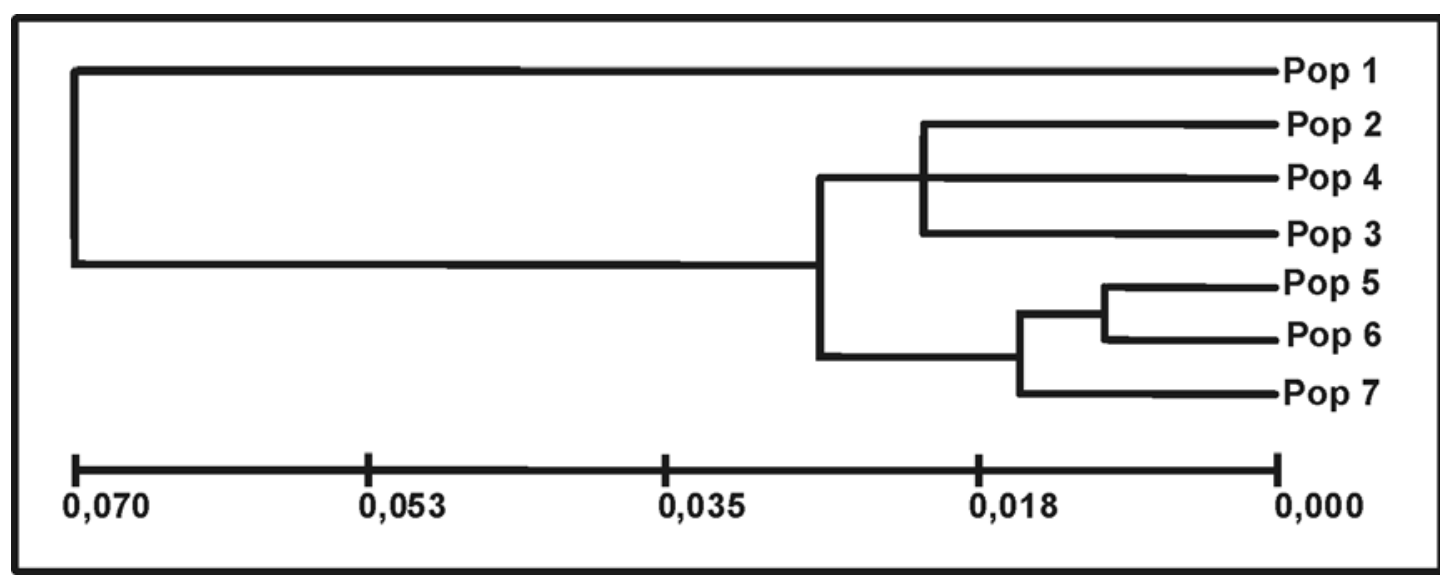

Figura 8 - Dendrograma de agrupamento UPGMA, Nei (1978).

\subsection{Análise da distribuição espacial da espécie na paisagem estudada}

Apenas 75 indivíduos com CAP superior a 60cm foram localizados; destes 42 estão localizados dentro de fragmentos (densidade de 0,32 por ha.) e 33 estão localizados em formações não florestais (densidade de 0,008 por ha.). Os dados indicam maciça preferência por ambientes florestais.

As figuras 4 e 5 apresentam o resultado da krigagem indicativa realizada com os dados provenientes do fragmento Água Sumida, as linhas espessas representam os limites da floresta remanescente, onde se abriga a população 6 . 


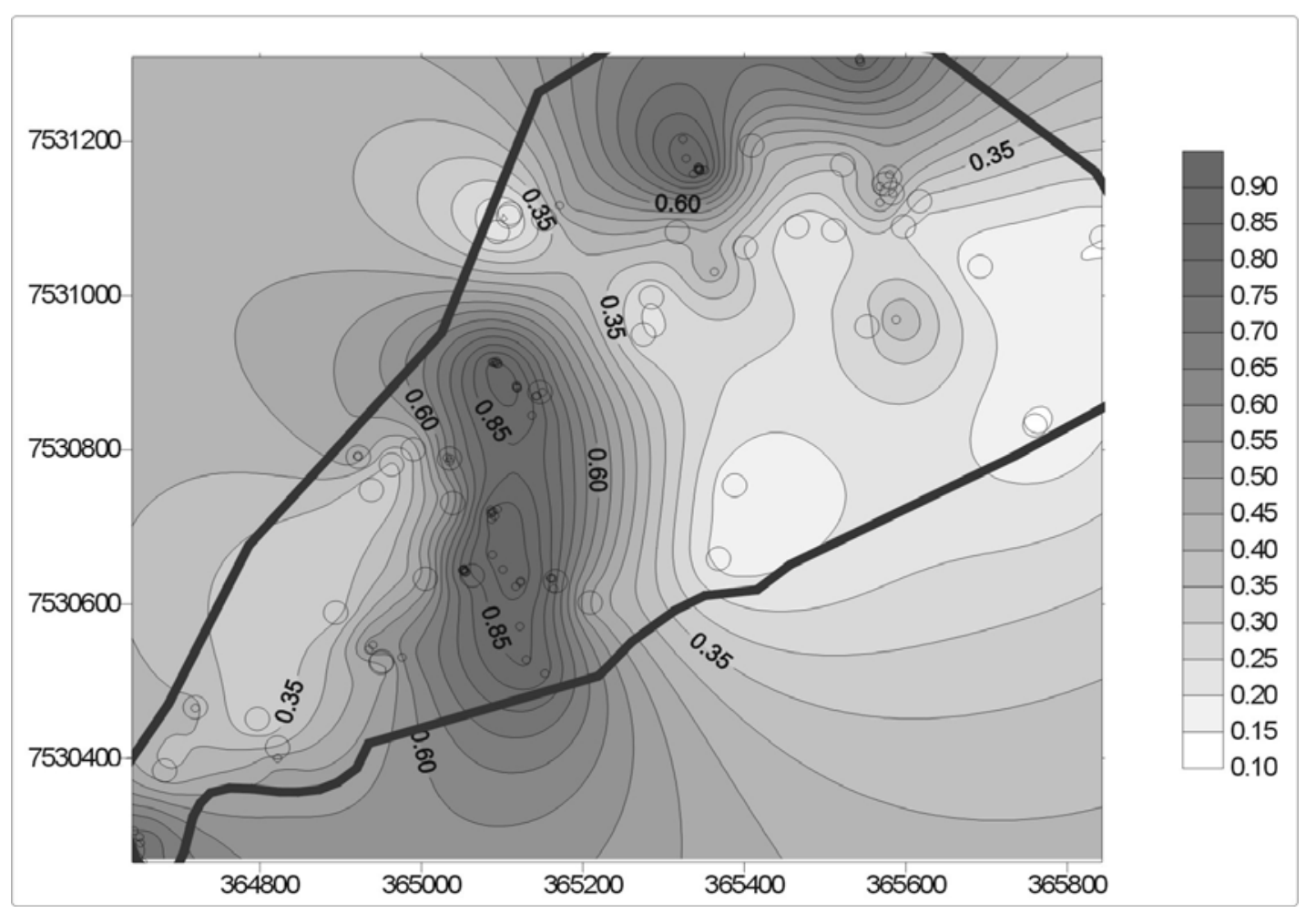

Figura 9 - Mapa isoplético de densidade relativa (plântulas/adultos) para população 6. As áreas com maiores valores representam áreas com predominância de plântulas, e as áreas com menores valores representam predominância de adultos. O traço espesso representa o atual limite da floresta remanescente da mata Água Sumida, a cobertura vegetal periférica é composta por campos.

Pode ser observada, na latitude 365100, uma tendência vertical de ausência de indivíduos adultos. Este padrão, mais nítido na figura 9, pode indicar uma antiga via de extração de madeira. Porém, durante o trabalho de campo não foi encontrado nenhum vestígio de corte seletivo nesta região.

A figura 4 indica que os resultados dos processos, que interferem na distribuição de plântulas, tais como dispersão de sementes, germinação e predação de cotilédones, não parecem ser fortemente influenciados pela proximidade da borda. 
Caso o resultado da interação destes processos fosse negativamente influenciado pelo efeito de borda, seria observada uma tendência de concentração de plântulas no centro do fragmento, e caso fossem influenciados positivamente seria observada a concentração nas bordas.

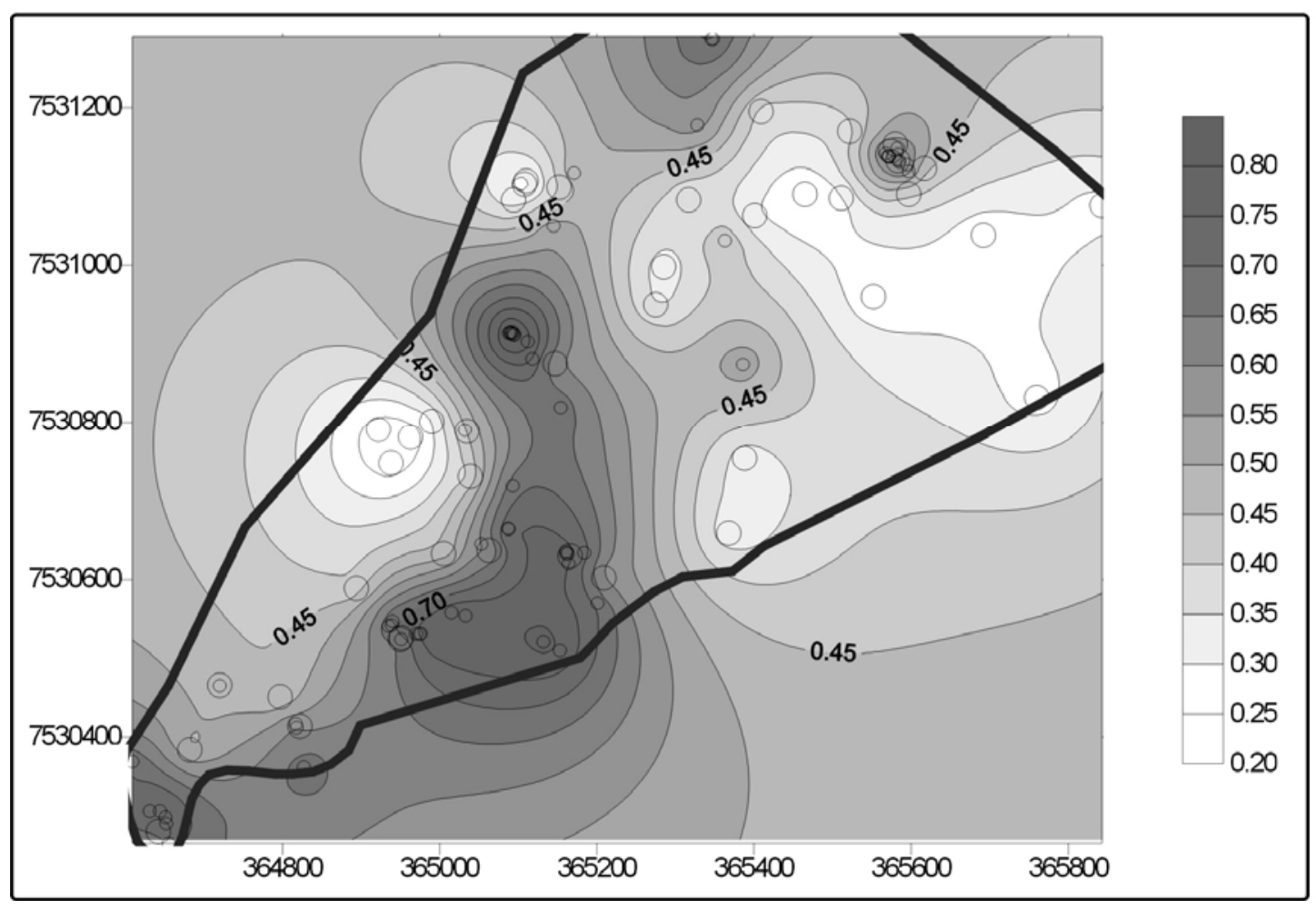

Figura 10 - Mapa isoplético de densidade relativa (jovens/adultos) ) para população 6.

As áreas com maiores valores representam áreas com predominância de jovens

Da mesma maneira, a distribuição de jovens, resultado de processos como a sobrevivência de plântulas e competição por recursos, não demonstrou, nesta análise exploratória, influência do efeito de borda.

As hipóteses levantadas pela krigagem indicativa são de que não existe relação entre a distância da borda e a distribuição dos jatobás, e que esta indiferença seria comum a todas as classes de tamanho adotadas. Estas hipóteses foram testadas e confirmadas pela análise de variância. A ANOVA resultante indica que a densidade de 
jatobás não possui correlação com a distância da borda $(\mathrm{p}=0,35)$, e que a distância de borda não produz diferenciação quanto à distribuição das classes de tamanho $(p=0,44)$, como indicado na tabela 4.

Tabela 4. ANOVA distância das bordas - para número de plantas por 100 grids

\begin{tabular}{cccccc}
\hline Fonte de variação & gl & SQ & QM & F & p \\
\hline Distância da borda & 4 & 4339,97 & 1085,0 & 1,49 & 0,35 \\
Classes de CAP & 1 & 545,30 & 545,30 & 0,75 & 0,44 \\
Resíduo & 4 & 2915,47 & 728,9 & & \\
Total & 9 & 7800,74 & & & \\
\hline
\end{tabular}

Os resultados destas análises sugerem que o jatobá não apresenta restrições de habitat quanto a tamanho ou forma do fragmento, por ser indiferente ao efeito de borda. Desta maneira, todos os fragmentos mapeados foram considerados como habitat potencial.

\subsection{Análises em SIG}

O mapeamento de fragmentos florestal é apresentado em anexo D. Este mapeamento apresenta a cobertura florestal do Pontal do Paranapanema dividida em 162 polígonos. Todos os fragmentos mapeados foram considerados como habitat, como foi indicado pela análise da distribuição espacial do jatobá. Desta forma, as análises se basearam nestes 162 fragmentos.

A análise de buffer, para distância limiar de $1600 \mathrm{~m}$, realizada sobre o mapeamento de fragmentos detectou a presença de 58 sub-grafos, que seriam grupos de fragmentos dentro dos quais espera-se troca de sementes e colonização, com base nos dados obtidos no conjunto de populações amostradas. Esta análise de buffer é apresentada em anexo E.

A proporção de 58 sub-grafos para 162 fragmentos indica o baixo grau de conectividade da Paisagem do Pontal do Paranapanema para a espécie guarda-chuva Hymenaea courbaril. O anexo E ainda indica que para a espécie não existe uma rede 
principal de fragmentos. Existem apenas pequenos agrupamentos, de forma que não é possível ordenar os fragmentos por grau de contribuição à conectividade da paisagem baseando-se na análise do sistema de rede de dispersão desta espécie.

O anexo F apresenta a mesma análise de buffer de anexo E, porém considerandose um cenário onde toda a APP ripária é florestada. Neste caso, 13 fragmentos, inseridos em 12 sub-grafos, continuariam em situação de isolamento. A análise indica também que a recuperação de APPs ciliares causariam um grande impacto positivo para a conectividade entre populações remanescentes de Hymenaea courbaril. 


\section{CONCLUSÕES}

A análise da distribuição espacial de jatobá na floresta remanescente do Fragmento “Água Sumida” indica que esta espécie não sofre efeitos negativos da proximidade da borda. Este resultado indica que apesar de esta ser uma espécie rara, o jatobá é adaptado às condições de alta perturbação, podendo germinar e ser recrutado em condições de maior luminosidade e de microclima semelhante ao de pastos. Este resultado ainda indica que as populações recolonizantes (3, 5 e7) podem ter se estabelecido diretamente sobre as pastagens.

A distribuição das distâncias de fluxo de sementes amostradas demonstra que, na área de estudo, o jatobá é amparado por uma eficiente interação de zoocoria, uma vez que dos 62 eventos dispersivos identificados 11 eram representados por distâncias superiores a $1 \mathrm{Km}$.. È necessário considerar que a distribuição das distâncias amostradas sofreu interferência de diferentes “peneiras” de recrutamento, uma vez que os "filhos" considerados possuem idades distintas.

Os dados demográficos e genéticos levantados, no conjunto de populações amostradas, não descartam a possibilidade de que o jatobá possa ser analisado segundo a dinâmica de metapopulação clássica na área amostrada.

A estrutura da paisagem do Pontal do Paranapanema sugere que nesta paisagem existiriam poucos conjuntos de populações conectadas de jatobá, a maior delas inclui os indivíduos do PE Morro do Diabo, e, caso este conjunto de populações se enquadre como metapopulação, provavelmente seria do tipo continente-ilha. 
Em geral, a modelagem de metapopulações busca a extrapolação temporal das dinâmicas de recolonização e extinção local. Este trabalho propõe uma metodologia de extrapolação espacial da dinâmica de recolonização, que concluímos ser uma eficiente forma de avaliação de intervenções de manejo de paisagens, tais como os corredores ecológicos. Nesta metodologia os resultados se enriquecem à medida que são ampliados os números de fragmentos amostrados e a quantidade de espécies estudadas.

A análise de conectividade baseada na distância limiar de dispersão para Hymenaea courbaril indica que o pontal do Paranapanema é uma paisagem de baixa conectividade, onde predominam populações isoladas.

Os resultados desta pesquisa reforçam que a recuperação de Àreas de Preservação Permanentes (APP) é um passo fundamental na recuperação de conectividade da paisagem do Pontal do Paranapanema. O Código Florestal favorece fragmentos inseridos em regiões bem drenadas. No Pontal do Paranapanema ocorrem muitas localidades distantes de rios e nascentes. Do ponto de vista da espécie estudada, nestas condições são necessárias medidas adicionais de incremento de conectividade.

Metodologia análoga à utilizada pelo presente trabalho pode auxiliar no controle de plantas invasoras. Ao modelar a distância de dispersão de sementes destas espécies é possível estimar as distâncias, máxima e média, percorridas em uma geração. Através de SIG seria possível identificar possíveis rotas de colonização e áreas mais vulneráveis.

O interesse pelas informações oferecidas pela dispersão de sementes é antigo, e grandes avanços têm sido obtidos nas abordagens de Autoecologia e Ecologia de Interações. Porém, sob o ponto de vista da Ecologia de Populações, o mapeamento da dinâmica espacial de eventos de dispersão de sementes apresentava uma lacuna até pouco tempo, pois a possibilidade de mapear o produto da destes eventos com a precisão adequada é bastante nova. A difusão da utilização de marcadores de microssatélites, e de receptores GPS é recente. E ainda mais recente é a 
disponibilização de primers para DNA cloroplastidial e de receptores GPS com precisão sub-decamétrica.

Metodologias adequadas a estas novas tecnologias, como a utilizada neste trabalho, podem ser consideradas como pioneiras, e, neste sentido, ainda devem ser aprimoradas em trabalhos futuros, como conseqüência das próprias análises dos resultados obtidos.

Nesta pesquisa, foi observado que populações pequenas são extremamente informativas, sugerindo, assim, que as análises apresentadas teriam um ganho em precisão com a adição de populações pequenas, analisadas com baixo custo. Este ganho seria ainda maior se estas novas populações oferecessem uma melhor distribuição de distâncias entre fragmentos para análise. Além de preencher lacunas de distâncias, estas novas populações poderiam adicionar fragmentos ainda mais próximos e fragmentos ainda mais distantes nas análises.

Outra sugestão, no sentido de aumentar a precisão das análises, seria ampliar o número de haplótipos analisados, pela inclusão da análise locos polimórficos de DNA cloroplastídico.

A modelagem espacial do fluxo de sementes, através da utilização de marcadores moleculares e SIG, pode ser considerada como uma promissora ferramenta ao manejo de paisagens. Este eficiente, e preciso, indicador de fluxos biológicos pode ser analisado em prazos curtos e com custo acessível, considerando-se o volume de recursos que são empenhados na implementação de projetos de manejo de paisagens.

A metodologia adotada também se mostrou uma eficiente forma de investigação das implicações espaciais da biologia reprodutiva da espécie estudada, este é um importante dado para estudos de manejo e regeneração de jatobá, na Paisagem do Pontal do Paranapanema. 
ANEXOS 


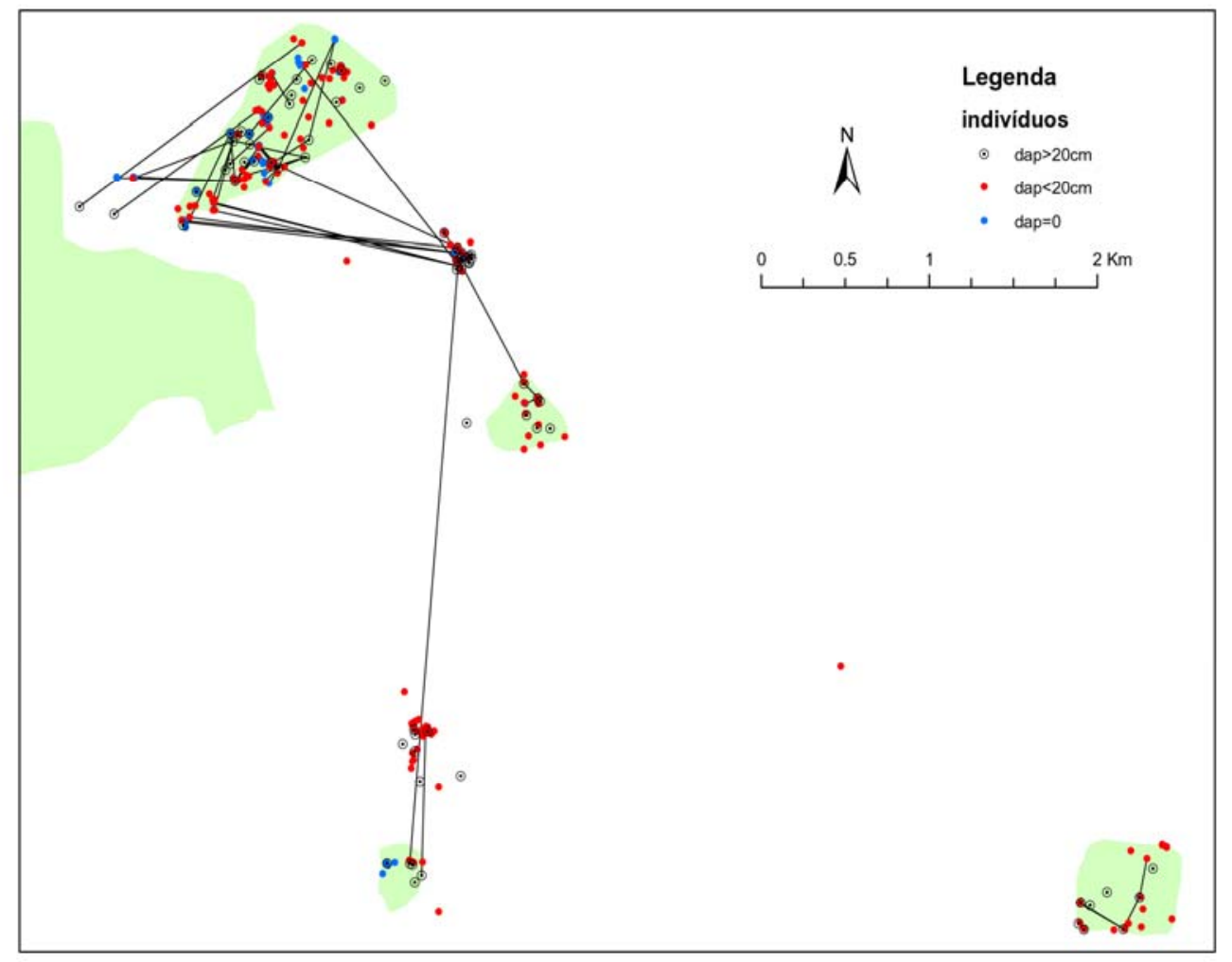

Anexo A - Fluxos de sementes detectados 


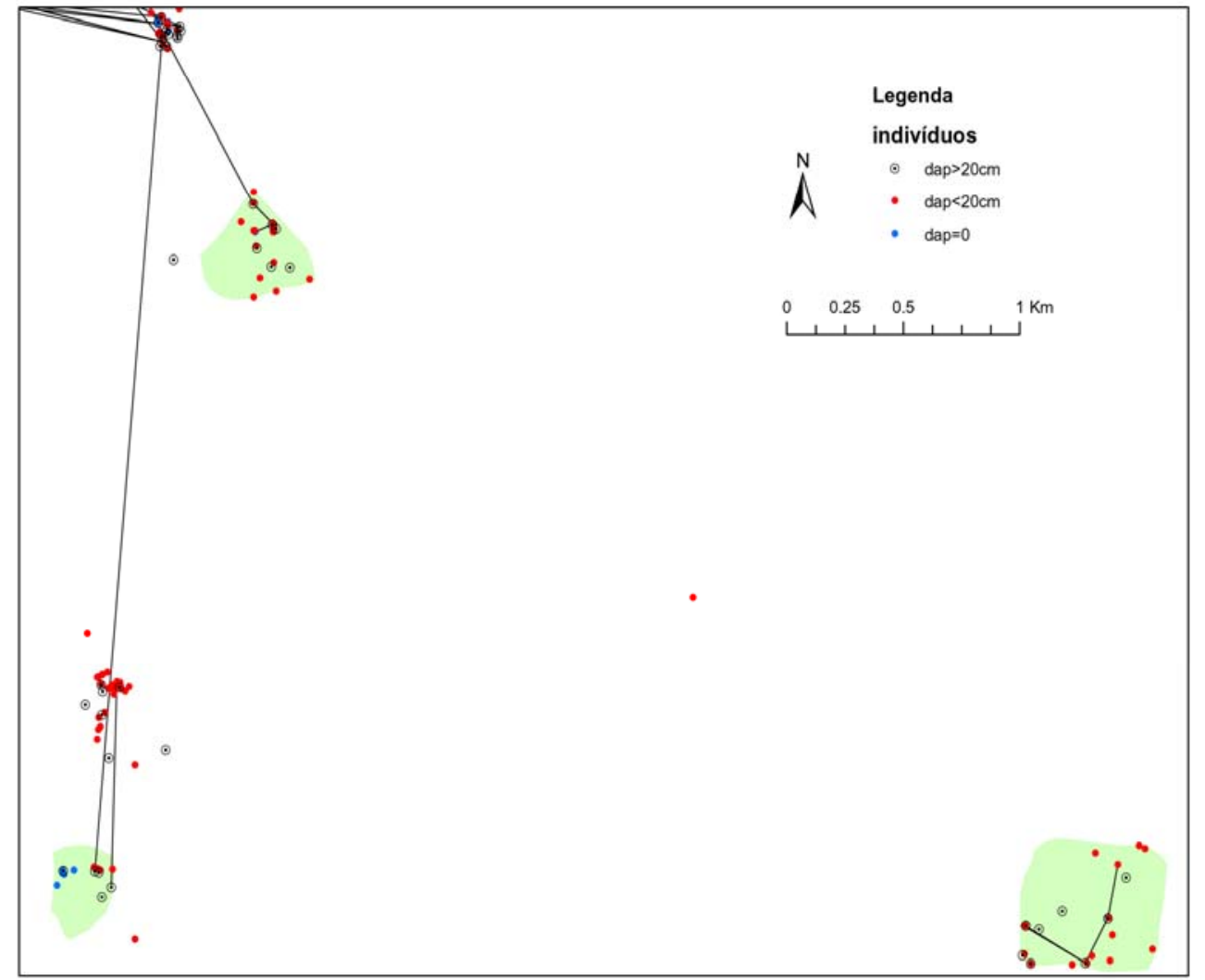

Anexo B - Fluxos de sementes detectados, porção Sul. 


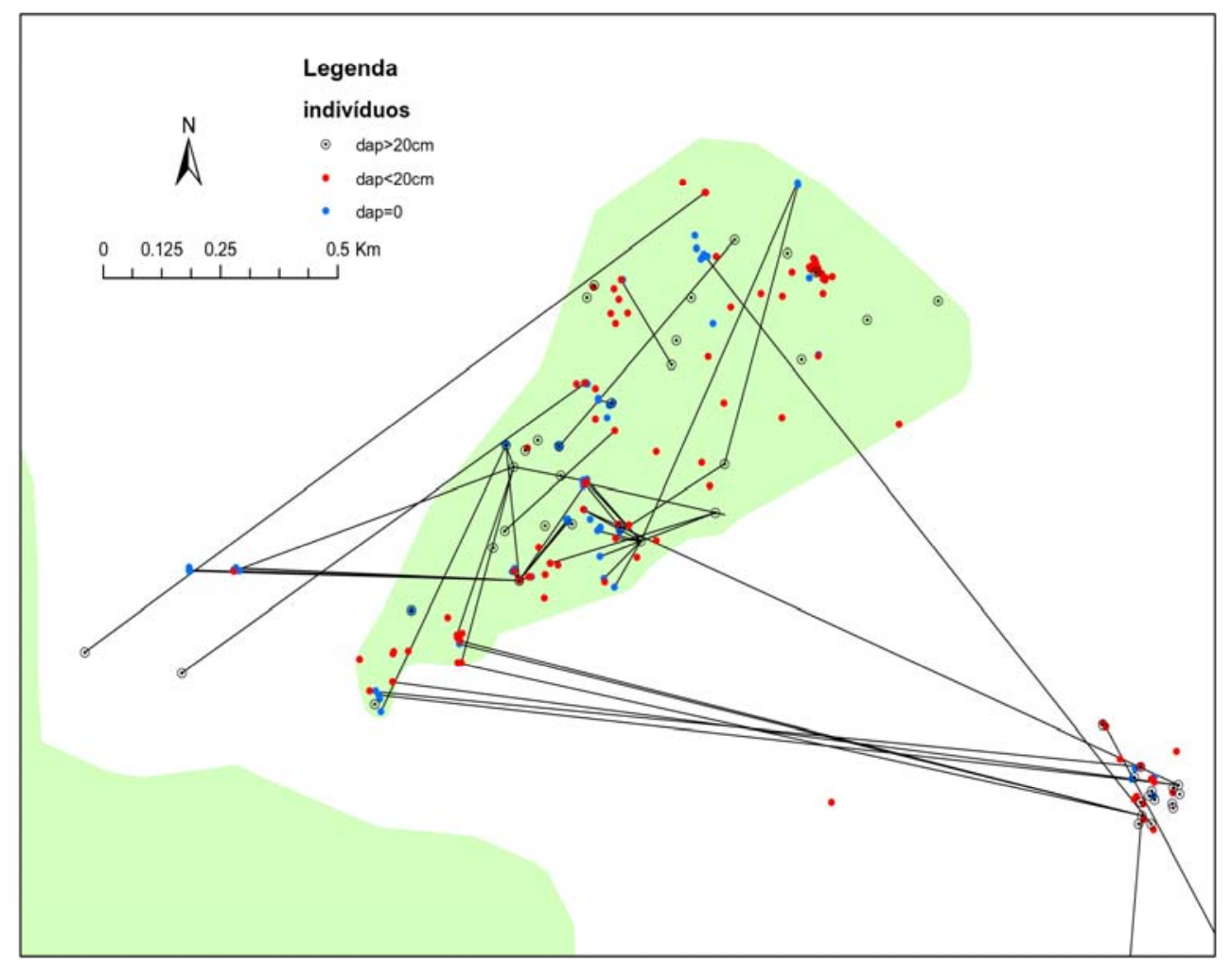

Anexo C - Fluxos de sementes detectados, porção Norte. 


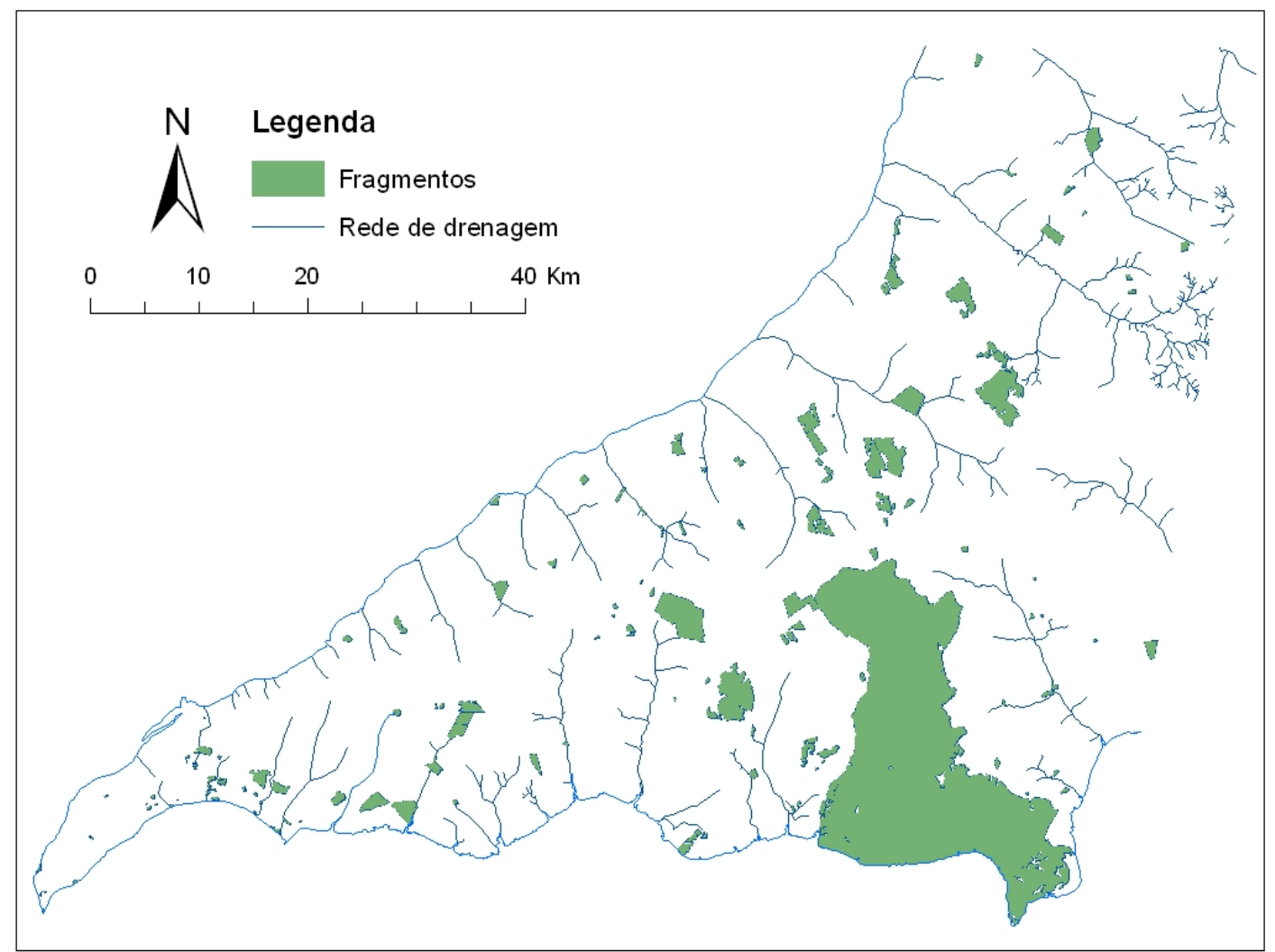

Anexo D - Fragmentos mapeados do Pontal do Paranapanema, P.E. Morro do Diabo no extremo sudeste. 


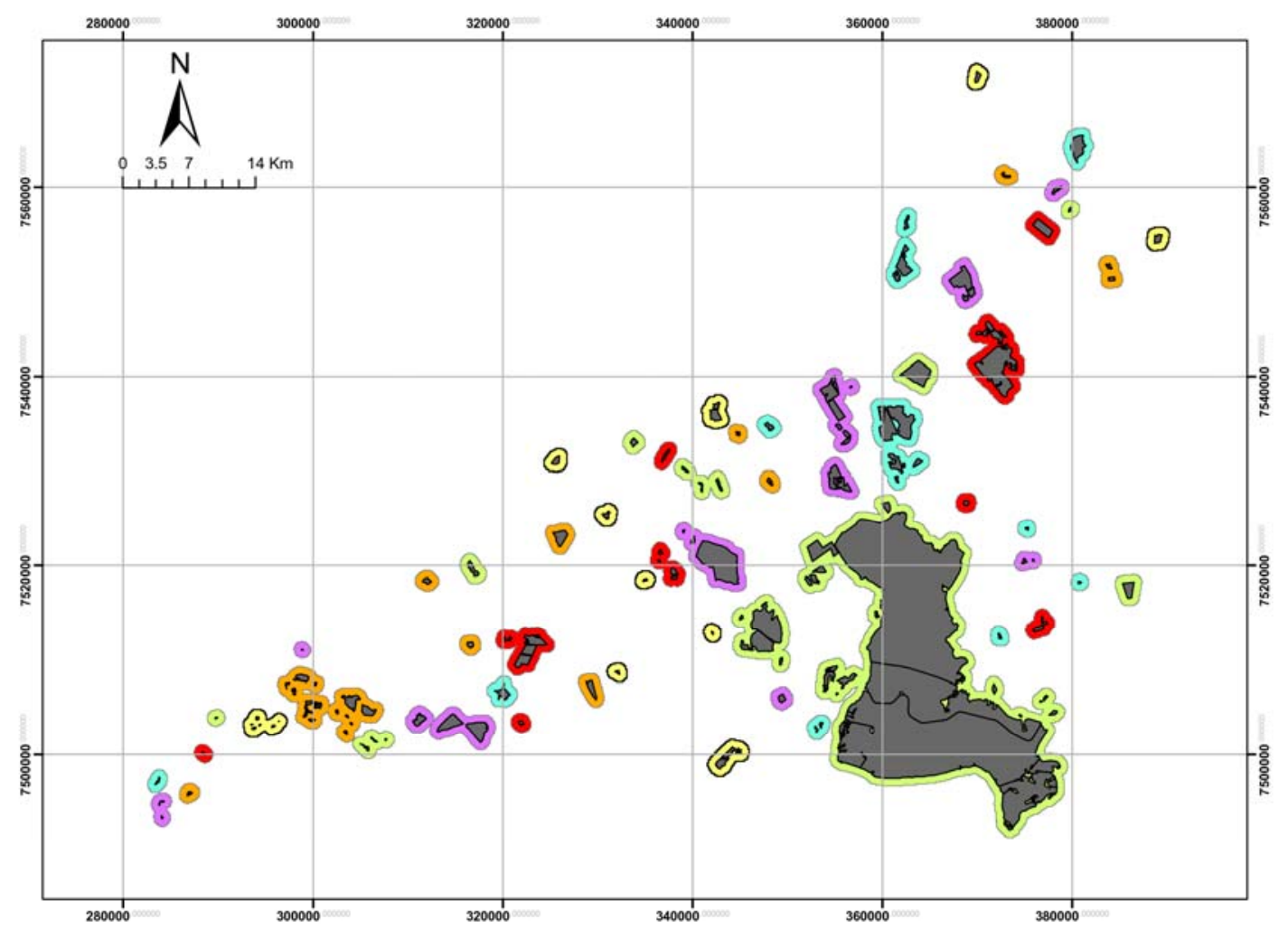

Anexo E - Subgrafos identificados, distância limiar de 1600m. 


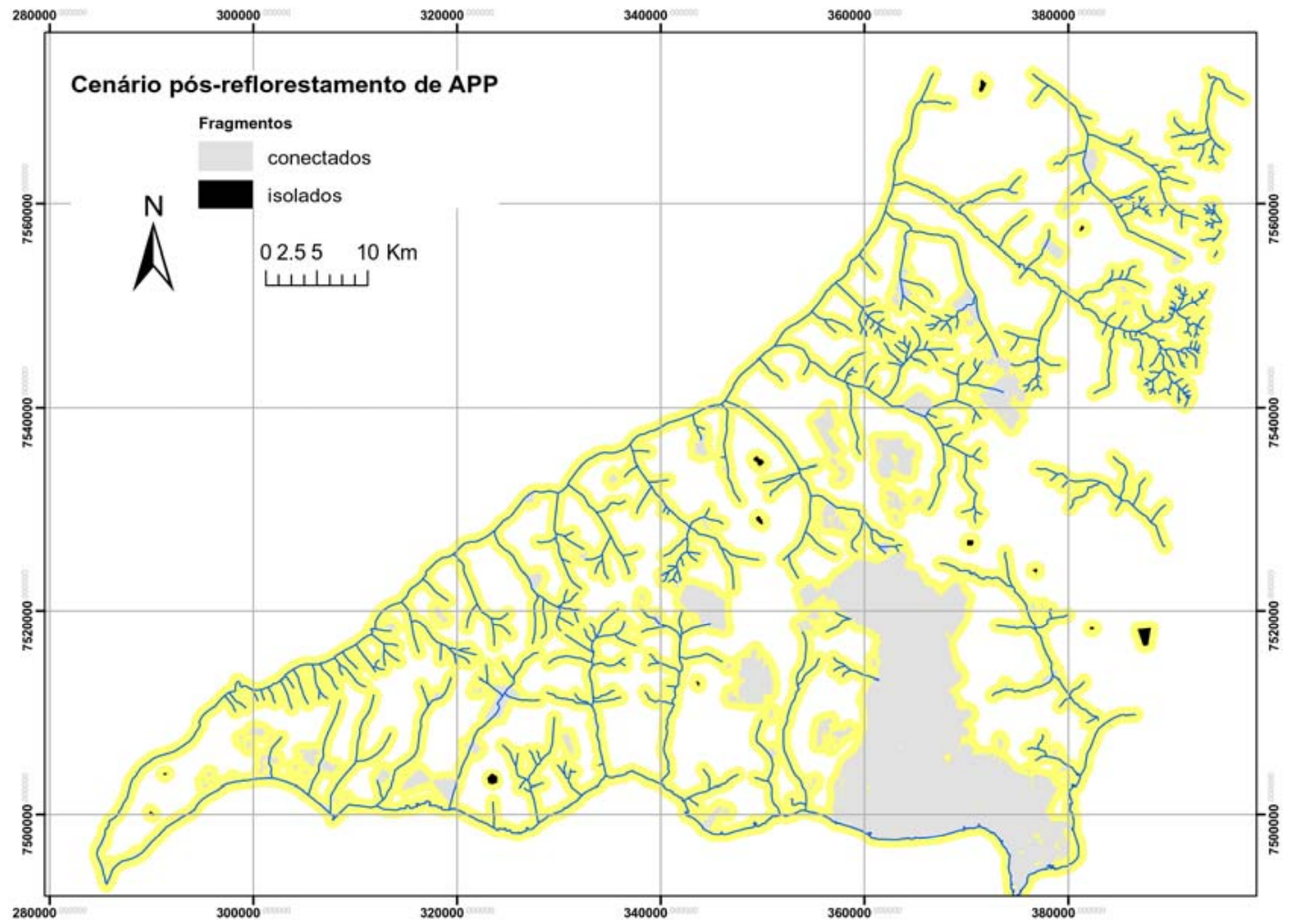

Anexo F: Isolamento de fragmentos após reflorestamento de APPs, buffer de 800m. 


\section{REFERÊNCIAS BIBLIOGRÁFICAS}

BAZZAS, F. A.; PICKET, S.T.A. Physiological ecology of tropical succesion: a comparative review. Annual Review of Ecology and Systematics. v.11. p.287310,1980 .

BRASIL. Lei $n^{0} 4.771$ de 17 de setembro de 1965. Diário Oficial, 19 set 1965. Seção 1, p.2-6. Dispõe sobre o código florestal brasileiro.

BUNN, A.G.; URBAN, D. L.; KEITT, T. H. Landscape connectivity: A conservation application of graph theory. Journal of Environmental Management. v.59. p.265-278, 2000.

CAIN, M.L.; BROOK, G. M.; STRAND, A.E. Long-distance seed dispersal in plant population. American Journal of Botany, v.87, n. 9, p.1217-1227, 2000.

INSTITUTO DE TERRAS (SP) Pontal Verde: plano de recuperação ambiental nos assentamentos do Pontal do Paranapanema, Secretaria da Justiça e da Defesa da Cidadania - Itesp, São Paulo, 1998, 60 p. (cadernos ITESP, 2).

COCKERHAM, C.C.; WEIR, B.S. Covariances of relatives stemming a population undergoing mixed self and random mating. Biometrics 40, p. 157-164, 1984.

CORRY, R.C.; NASSAUER, J.I. Managing for small-patch patterns in human dominated landscapes: cultural factors and corn belt agriculture. in: LIU, J.;TAYLOR, W.W. Integrating landscape ecology into natural resource management. Cambridge: Cambridge University press, 2002. p.92-114. 
CRAWLEY, M. J. Plant Ecology. Londres: Blackwell Science, 1997. 370p.

CRESTE, C.; TULMANN NETO, A.; FIGUEIRA, A. Detection of single sequence repeat polymorphisms in denaturing polyacrylamide sequencing gels by silver staining. Plant Molecular Biology Reporter, v. 19, p. 299-306, 2001.

DARWIN, C. A origem das espécies. Belo Horizonte: Villa Rica, [1859]1994 . 354p.

DEAN, W. A Ferro e Fogo: a história e a devastação da mata atlântica brasileira. Companhia das Letras, São Paulo, p.34-57, 1996.

DITT, E.H. Diagnóstico da conservação e das áreas ameaçadas a fragmentos florestais no Pontal do Paranapanema, São Paulo. São Paulo, 2000. 97p. Dissertação de (Mestrado) PROCAM, Universidade de São Paulo.

DUNPHY, B.K.; HAMRICK J.L.; SCHWAGERL, J. A comparison of direct and indirect measures of gene flow in the bat-pollinated tree Hymenaea courbaril in the dry forest life zone of southwestern puerto rico. International Journal of Plant Sciences, v.165, p.427, 2004.

EFRON, B.; TIBSHRANI, R. An introduction to bootstrap. Nova York: Chapman \& Hill, 1993. 436p.

FERRAZ, G.; RUSSELL, G.J.; STOUFFER, P.C.; BIERREGAARD, R.O.; PIMM S.L.; LOVEJOY, T.E. Rates of species loss from Amazonian forest fragments . Proceedings of the National Academy of Science of USA. v.100,n. 24, p.1406914073, 2003.

FERREIRA, M.E.; GRATTAPAGLIA, D. Introdução ao uso de marcadores RAPD e RFLP em análise genética. Embrapa , Cenargen, 1995. 220p.

FORMAN, R.T.T. Land mosaics: the Ecology of landscapes and regions. Cambridge: Cambridge press, 1995. 632p. 
FORMAN, R.T.T. Epilogue. in: LIU, J.;TAYLOR, W.W. Integrating landscape ecology into natural resource management. Cambridge: Cambridge University press, 2002. p.466-472.

GAIOTTO, F. A.; GRATTAPAGLIA, D.; VENCOVSKY, R. Genetic structure, mating system, and long-distance gene flow in heart of palm (Euterpe edulis Mart.). Journal of Heredity, v.94, p.399-406, 2003.

GODOY, J.A.; JORDANO, P. Seed dispersal by animals: exact identification of source trees with endocarp DNA microsatellites. Molecular Ecology, v.10, p.2275-2283, 2001.

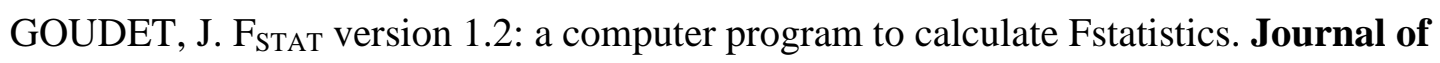
Heredity, 86n.6, 485-486, 1995.

HAMRICK, J.L.; LOVELESS, M.D. The genetic structure of tropical tree populations: associations with reproductive biology. In: BOCK, J.H.; LINHART, Y.B. The evolutionary ecology of plants. Bouder: Wesview press, 1998. p.129-146.

HANSKI, I. Metapopulation theory, its use and misuse. Basic and Applied Ecology. v.5. p.225-229. 2004.

HANSKI, I.; OVASKAINEN,O. Metapopulation theory for fragmentedland scapes. Theoretical Population Biology. v.64. p.119-127. 2003.

HANSKI,I, Metapoplulation Dynamics, Nature. v.396. p.41-49, 1998.

JANZEN, D. H. Herbivores and the number of tree species in tropical forests. American Naturalist, v.104, p.501-508, 1970.

JORDÁN, L; BÁLDI, A.; ORCI, K.M.; RÁCZ I.; VARGA, Z. Characterizing the importance of habitat patches and corridors in maintaining the landscape 
connectivity of a Pholidoptera transsylvanica (Orthoptera) metapopulation. Landscape Ecology, v.18,p. 83-92, 2003.

KAGEYAMA, P.Y.; GANDARA, F.B. Dinâmica de espécies arbóreas: implicações para manejo e a conservação. in: Simpósio de Ecossistemas da costa brasileira: subsídios a um gerenciamento ambiental v.2. Anais São Paulo: São Paulo, ACIESP, 1994. p.17-24.

KAGEYAMA, P.Y.; GANDARA, F.B. Conseqüências genéticas da fragmentação sobre populações de espécies arbóreas. 53-56. in: Simpósio brasileiro sobre fragmentação ambiental. São Paulo, anais: São Paulo,ACIESP, 1999. p.53-56

KAMEYAMA, Y.; ISAGI,Y.; NAKAGOSHI, N. Patterns and levels of gene flow in Rhododendron metternichii var. hondoense revealed by microsatellite analysis. Molecular Ecology, v.10, p.205-216, 2001.

KITAMOTO, N.; HINJO, M.; UENO, S.; TAKENAKA, A.; TSUMURA, Y.; WASHITANI, I.; OHSAWA,R. Spatial genetic structure among and within populations of Primula sieboldii growing beside separate streams. Molecular Ecology, v. 14, p.149-157, 2005.

LAMBECK, R.J. Focal species: a multi-species umbrella for nature conservation. Conservation Biology, v. 11, p.849-856, 1997.

LANDIM, P.M.B. ; STURARO, J.R. Krigagem indicativa aplicada à elaboração de mapas probabilísticos de riscos. DGA,IGCE,UNESP/Rio Claro: Lab. Geomatemática. 2002. 19p. (TextoDidático) 06. http://www.rc.unesp.br/igce/aplicada/textodi.html. (10 nov 2004).

LANDIN, P. M. B. Análise estatística de dados geológicos. [S.I.]: Ed. UNESP, 1997. 19p. 
LEWIS, P.O.; ZAYKIN, D. Genetic Data Analysis: Computer program for the analysis of allelic data. Version 1.0 (d15). Free program distributed by the authors over the internet from de GDA homepage at http://alleyn.eeb.uconn.edu/gda/2000. 2000.

MANTEL, N. The detection of disease clustering and a generalized regression approach. Cancer Research v.27, p.209-220. 1967.

MENNECHEZ, G.; PETIT, S.; SCHTICKZELLE, N.; BAGUETTE, M. Modelling mortality and dispersal: consequences of parameter generalisation on metapopulation dynamics.Oikos, v.106, p.243-252, 2004.

METZGER. J.P. Como restaurar a conectividade em paisagens fragmentadas. in: KAGEYAMA, PK.; OLIVEIRA, R.E.; MORAES, L.F.D.; GANDARA, F.B. Restauração ecológica de ecossistemas naturais. Botucatu: FEPAF, 2004. p.340.

METZGER, J. P.; DÉCAMPS, H. The structural connectivity threshold: an hypothesis in conservation biology at the landscape scale. Acta OecologicaInternational Journal of Ecology, v.18 n.1, p.1-13, 1997.

MILLER, J.R.; HOBBS, R.J. Conservation where people live and work. Conservation Biology, 16 n. 2, p.330-337, 2002.

MILLER, M.P. Tools for population genetic analyses (TFPGA) v 1.3. A Windows program for the analysis of allozyme and molecular population genetic data. Computer software distributed by author. 1997.

MILLER, R. I. Mapping the diversity of nature. Londres: Chapman \& Hill, 1994. 218p.

NETER, J.; KUTNER, M.; NACHTSHEIM; C.; WASSERMAN, W. Applied linear statistical models. Chicago: Irwin, 1996. 1408p. 
OPDAM, P. Populations in fragmented landscape. in: SCHREIBER K.F,. Arbeiten, 1988, Connectivity in landscape ecology :Proceeding of the 2nd Int.Seminar of the "Int. Association for Landscape Ecology". [S.I.]. Münstersche Geographischen. p.75-77.

OUBORG, N.J. Isolation, population size and extinction : the classical and metapopulation approaches applied to vascular plants along the Dutch Rhinesystem. Oikos, v. 66, p.298-308,1993.

PRANDINI, F.L. Mapa Geomorfológico do Estado de São Paulo, São Paulo : Instituto de Pesquisas Tecnológicas, 1981.

ROHLF, F.J. NTSYS-Pc: Numerical taxonomy and multivariate analysis system., New York: Exeter publisher 1989. 621 p.

SANTOS, J.D. Estudos ecológicos e genéticos numa paisagem fragmentada visando sua conectividade, no pontal do Paranapanema - SP.Piracicaba. 2002. 101p. Dissertação de (Mestrado), Escola Superior de Agricultura Luiz de Queiroz, Universidade de São Paulo.

SISK, T.D.; HADDAD, N.M. Incorporating the effects of habitat edges into landscape models: Effective area models for cross-boudary managemen. in: LIU, J.;TAYLOR, W.W. Integrating Landscape ecology into natural resource management.Cambridge: Cambridge University press, 2002. p.208-240.

SORK, V.L.; NASON J.; CAMPBELL, D.; FERNANDEZ .J. Landscape approaches to historical and contemporary gene flow in plants. Trends in Ecology \& Evolution, v. 14, n. 6, p.219-224, 1999.

THOREAU, H.D. Waldem ou a vida nos bosques e a desobediência civil. São Paulo: Aquariana, [1854], 2001. 346p. 
TURNER, M.G.; CROW, T.R.; LIU, J.; RABE, D.; RABENI, C.; SORRANO, P.A.

Bridging the gap between landscape ecology and natural resource management. in: LIU, J.;TAYLOR, W.W. Integrating Landscape ecology into natural resource management. Cambridge: Cambridge University press, 2002. p.433-460.

URBAN, D. L.; KEITT, T. H. Landscape connectivity: a graph-theoretic perspective, Ecology, v.82 n.5, p.1205-1218, 2001.

USHIZIMA, T. M.; BERNARDI, J. V. E.; LANDIM, P. M. B. Estudo da distribuição espacial do Angico (Anadananthera peregrina) na Floresta Estadual Edmundo Navarro de Andrade - Rio Claro, SP, empregando metodologia geoestatística. HOLOS Environment, v.3, n.1, p.59-73, 2003.

VELOSO, H.P; RANGEL-FILHO, A.L.; LIMA, J.C.A. Classificação da vegetação brasileira, adaptada a um sistema universal, Rio de Janeiro: Fundação Instituto Brasileiro de Geografia e Estatística - IBGE, 1991.

VERHEYEN, K.; VELLEND, M.; CALSTER, H.V.; PETERKEN, G.; MARTIN,H. Metapopulation dynamics in changing landscapes: a new spatially realistic model for forest plants. Ecology. v. $\quad$ 85(12) p.3302-3312. 2004.

WANG, B.C.; SMITH, T.B. Closing the seed dispersal loop. Trends in Ecology \& Evolution. v.17 n.8. p.379-385. 2002.

WEIR, B.S. Genetic data analysis II. Sunderland, Massachusetts: Sinauer Associates. 1996. 445p.

WEISING, K.; GARDNER, R.C. A set of conserved PCR primers for the analysis of simple sequence repeat polymorphisms in chloroplast genome of dicotyledonous angiosperms. Genome, n.42, p.9-19, 1999. 
WILCOVE, D.S.; ROTHSTEIN, D.; DUBOW, J.; PHILLIPS, A., LOSOS, E.

Quantifying threats to imperiled species in the United States. BioScience, v.48, p.607-615,1998.

WILSON, E. O. Diversidade de vida. São Paulo: Editora Companhia das Letras, 1994. 359p.

WRIGHT, S. The genetical structure of populations. Annual Eugenics, n.15, p.323354,1951 .

YOUNG, A.; BOYLE, T.; BROWN, T. The population genetic consequences of habitat fragmentation for plants. Trends in Ecology \& Evolution, v.11, n.10, p. 413-418, 1996. 